\title{
Variation of growth and phenology traits in poplars planted in clonal trials in Northern Europe-implications for breeding
}

\author{
Anneli Adler ${ }^{1}$ (D) Almir Karacic ${ }^{1}$ (D) $\cdot$ Ann-Christin Rönnberg Wästljung ${ }^{2}$ (D) $\cdot$ Ulf Johansson $^{3} \cdot$ Kaspars Liepins $^{4}$ (D) $\cdot$ \\ Audrius Gradeckas ${ }^{5} \cdot$ Lars Christersson $^{1}$ (D)
}

Received: 8 July 2020 / Accepted: 17 February 2021 / Published online: 6 March 2021

(C) The Author(s) 2021

\begin{abstract}
The increased demand for wood to replace oil-based products with renewable products has lifted focus to the Baltic Sea region where the environment is favorable for woody biomass growth. The aim of this study was to estimate broad-sense heritabilities and genotype-by-environment $(\mathrm{G} \times \mathrm{E})$ interactions in growth and phenology traits in six climatically different regions in Sweden and the Baltics. We tested the hypothesis that both bud burst and bud set have a significant effect on the early growth of selected poplar clones in Northern Europe. Provenance hybrids of Populus trichocarpa adapted to the Northern European climate were compared to reference clones with adaptation to the Central European climate. The volume index of stemwood was under low to medium genetic control with heritabilities from 0.22 to 0.75 . Heritabilities for phenology traits varied between 0.31 and 0.91 . Locally chosen elite clones were identified. G×E interactions were analyzed using pairwise comparisons of the trials. Three different breeding zones for poplars between the latitudes of $55^{\circ} \mathrm{N}$ and $60^{\circ} \mathrm{N}$ in the Baltic Sea Region were outlined. The studied provenance hybrids with origin from North America offer a great possibility to broaden the area with commercial poplar plantations in Northern Europe and further improve the collection of commercial clones to match local climates. We conclude that phenology is an important selection criterion after growth.
\end{abstract}

Keywords Provenance hybrids · Populus · trichocarpa Sweden · Baltic countries · Volume index · Quantitative genetics · Heritability

\section{Introduction}

Medium Rotation Forests with fast-growing Populus species offer a significant complementary source of renewable raw materials for various industries worldwide [1]. Woody crops

Anneli Adler

anneli.adler@slu.se

1 Department of Crop Production Ecology, Swedish University of Agricultural Sciences (SLU), P.O. Box 7043,

SE-75007 Uppsala, Sweden

2 Department of Plant Biology, Swedish University of Agricultural Sciences (SLU), P.O. Box 7080, SE-75007 Uppsala, Sweden

3 Unit of Field-Based Forest Research, Swedish University of Agricultural Sciences (SLU), P.O. Box 17, SE-313 25, Simlångsdalen, Sweden

4 Department Forest Regeneration and Establishment, Latvian State Forest Research Institute (SILAVA), Salaspils LV-2169, Latvia

5 Euromediena UAB, S. Daukanto a, LT-01122 Vilnius, Lithuania with fast-growing deciduous species create an opportunity for efficient land use while providing a number of ecosystem services [2]. In recent years, the interest in poplars and the establishment of new plantations has been steadily increasing in the whole Nordic-Baltic region [3]. This trend has been promoted by the success of Swedish poplar plantations established at the beginning of the 1990s using a Populus maximowiczii Henry $\times P$. trichocarpa Torr. \& Gray hybrid "OP42." The mean annual biomass production in these plantations regularly reaches $10 \mathrm{Mg} \mathrm{DW} \mathrm{ha}{ }^{-1}$ year $^{-1}$ (25 to $30 \mathrm{~m}^{3}$ $\mathrm{ha}^{-1}$ year $^{-1}$ stemwood) within a rotation period of ca. 20 years [3-5].

However, further expansion of the area of poplar plantations in the region needs to be facilitated through an increased genetic variation of commercially deployable planting stock. This is particularly important as poplars are becoming of interest for planting at higher latitudes in Sweden or in continental climate conditions in the Baltic region. In a search for productive and climate-adapted poplar material for central Swedish conditions, Ilstedt [6] repeatedly tested more than 100 clones of intra- and interspecific hybrids of 
$P$. trichocarpa and $P$. deltoides W. Bartram ex Marshall $\times P$. trichocarpa hybrids originating below $50^{\circ} \mathrm{N}$, bred and selected in Geraardsbergen, Belgium. In spite of initially fast growth, many clones were eventually damaged by early autumn frosts and low winter temperatures owing to the late and insufficient bud set. Later on, Christersson tested the same material in southernmost Sweden at $55^{\circ} 39^{\prime} \mathrm{N}$ [7]. He also pointed out the vulnerability of the material to early autumn frosts, particularly of the $P$. deltoides hybrids, while evaluating a number of intraspecific $P$. trichocarpa hybrids as potentially usable in southern Sweden.

In another study of 54 poplar clones imported via Holland and grown at two sites in southern Sweden at $56^{\circ} \mathrm{N}$, the authors noticed a better growth of "balsam type" poplars (i.e., belonging to species and hybrids of the Tacamahaca section) compared to pure species and hybrids with $P$. nigra L. and $P$. deltoides [8]. Later on, this material was extended with clones from the IUFRO collection selected in Finland for winter hardiness, and also with a number of commercial clones $[9,10]$. Besides a strong influence of genotype on growth in terms of high broad-sense heritability, there was also a generally stable clonal performance over different sites and a positive correlation between the late autumn foliage coloration and growth, suggesting that clones having green canopy late in the autumn generally perform better. The positive relationship between lifetime growth, measured as increase in height or weight, and late cessation of growth in autumn, i.e., the length of the growth period, is welldocumented in common garden studies and clone trials of several Populus species [11-14]. Savage and CavenderBares [15] showed that northern species of Populus and Salix exhibited slower growth rates than southern species only when grown under shorter summer day lengths than expected in their native range. Rather, the apparent trade-off between growth and freezing tolerance was related to the adaptive phenology strategy. The conclusion was that Salix and Populus species should grow better under conditions more similar to those in their native environments. A similar conclusion was drawn by Evans et al. [16] from a common garden study of $P$. angustifolia, where the transfer of provenances both southwards and northwards resulted in poor growth due to either too early bud set or too late leaf senescence leading to autumn and winter frost damage. Consequently, we would expect that the adaptation of non-native poplar species in the NordicBaltic region would require the selection of clones with phenology that optimally match the local climate conditions in terms of timing of bud burst and bud set. In practice, this means that different clones will tend to be optimal for deployment at latitudes of $55^{\circ} \mathrm{N}, 60^{\circ} \mathrm{N}$, or $64^{\circ} \mathrm{N}$.

In an attempt to select commercially deployable material, the Swedish clone testing program was eventually broadened to include a wider range of latitudes, from $56^{\circ} \mathrm{N}$ to $65^{\circ} \mathrm{N}$, using additional material from northern provenances of
$P$. trichocarpa in Canada and Italian $P$. deltoides $\times P$. nigra hybrids [17]. The most important lessons from an early evaluation of these trials, which included pairs of forest and setaside agricultural sites, as well as a population of hybrid aspen (P. tremuloides Michx. $\times$ P. tremula L.), was that poplars had low survival and growth on the northern sites and were underperforming on forest sites compared to hybrid aspen. Despite poor genotypic correlations between growth and phenology for poplars in the above-mentioned study, the results indicated a tendency for positive correlation between growth and a combination of an early flushing and late leaf coloring, which can be interpreted as a positive effect of a longer green canopy duration on growth. Pliura et al. [18] also found the $P$. maximowiczii $\times P$. trichocarpa hybrids to be most suitable for the climate conditions in Lithuania when they compared growth and adaptive traits of 105 clones at two sites. The authors found that most adaptive traits were under strong genetic control with significant genotype-by-environment $(\mathrm{G} \times \mathrm{E})$ interactions for many growth traits. Furthermore, negative correlations between tree condition and autumn leaf shed phenology in their study indicated that trees with late growth cessation appear to suffer from adaptation problems. Consequently, the strong genetic control of growth and phenology traits allows for significant improvement of clonal performance through selection for adaptation to varying environmental conditions. Such a selection among hybrids and native individuals is oriented towards optimization of the transition between dormancy and growth at both ends of the growing season, prolonging it as much as possible while keeping the risk of frost damage at a reasonably low level [6, 19, 20].

In the $1990 \mathrm{~s}$, in an attempt to adapt $P$. trichocarpa to the climate in central Sweden, Ilstedt [21] made a large number of crossings between 13 female and 11 male $P$. trichocarpa parents of different geographic origins in North America resulting in approximately 7000 progenies. Since 2003, around 100 clones were selected for testing in a number of clonal trials in Sweden, Latvia, and Lithuania. This material is a subject of the present study in which we explore phenotypic variation, broad-sense heritability, and genotype-byenvironment $(\mathrm{G} \times \mathrm{E})$ interaction for a number of phenology and growth traits as well as survival. Our main hypothesis is that both bud burst and bud set have significant effects on early growth of poplars in the Baltic Sea Region. The specific aims are to (i) estimate the genotypic components of clonal variance of growth and phenology traits within each trial, (ii) to investigate if the observed early growth performance of poplar clones is correlated with their phenology within each trial, and (iii) to evaluate trait correlations between pairs of trials to identify $\mathrm{G} \times \mathrm{E}$ interaction. Finally, we aimed to (iv) outline major breeding zones for poplar in the Baltic Sea Region. This study will improve our knowledge about the genetic background in variation of growth and phenology traits in Northern Europe and advance our understanding of 
the possibilities to select commercially deployable clones after short-term testing by including phenology as an additional selection criterion after growth.

\section{Materials and methods}

\section{Field trials and poplar material}

We studied six clonal trials with poplars located in regions with variable climatic conditions around the Baltic Sea (Fig. 1). Two of the northernmost trials were located in central Sweden at $60^{\circ} 37^{\prime} \mathrm{N}$ and $59^{\circ} 83^{\prime} \mathrm{N}$ degrees of latitude (Tierp, Bodarna; Table 1). These two trials belong to different climatic zones according to Redalen [22]. Two clonal trials were located in Arlösa, southwestern Sweden, at $56^{\circ} 42^{\prime} \mathrm{N} ; 12^{\circ} 56^{\prime} \mathrm{E}$ and in Ludza, eastern Latvia, at $56^{\circ} 43^{\prime} \mathrm{N} ; 27^{\circ} 41^{\prime}$ E representing one maritime and one more continental site at this latitude. Similarly, with two Lithuanian trials, Anykščiai and Šašaičiai at $55^{\circ}$ $22^{\prime} \mathrm{N} ; 25^{\circ} 04^{\prime} \mathrm{E}$ and $56^{\circ} 01^{\prime} \mathrm{N} ; 22^{\circ} 20^{\prime} \mathrm{E}$, the first was located easterly in a more continental climate and the second westerly in a somewhat more maritime climate. A complete randomized block design with four blocks and five trees per clone and block was applied in Tierp and Ludza. A randomized block design with four blocks and one line plot of five trees per clone and block was applied in Bodarna and Arlösa, while single-tree plots in 16 replications were planted at Šašaičiai and Anykčiai (Table 1).

All six trials were established on productive former agricultural fields with diverse climatic [23-25] and edaphic conditions (Table 1; S1). Before planting, all the trials were fenced, ground vegetation was treated with the herbicide Round-up and the soil was plowed and harrowed. The two Lithuanian trials were planted with 30 -cm-long cuttings whereas the other four trials were established using containerized plants with shoot lengths of 40 to $100 \mathrm{~cm}$. The plants were pre-grown from 5- to 10 -cm-long cuttings 1 year before planting except for clone "OP42" in Ludza which was planted as $20 \mathrm{~cm}$ rooted cuttings pre-grown in a greenhouse 2 months before the trial was established. The green shoots of "OP42" were ca. $20 \mathrm{~cm}$ long at planting.

The tested poplar material belonged to four different groups: (1) provenance hybrids of $P$. trichocarpa bred at the Swedish University of Agricultural Sciences; (2) clones derived from selected individuals from natural populations of P. trichocarpa; (3) P. balsamifera in British Columbia, Canada, and (4) 24 reference clones, which are hybrids between different Populus species from diverse breeding programs (Table 2).

\section{Measurements and observations}

Measurements of tree diameter at breast height $(d b h)$ and tree height $(h)$, as well as survival inventories $(s)$, were conducted after 4 growing seasons between 2010 and 2017, in Arlösa, Tierp, Ludza, Šašaičiai, and Anykčiai, and after 7 growing seasons at Bodarna. The clonal performance was assessed on the basis of volume index $v_{i}=d^{2} h$. In addition, an assessment of spring phenology in all trials and an assessment of autumn phenology in the Baltic trials were conducted according to the scale described in Table 3. Spring and autumn phenology were examined, to determine if growth of poplar clones in different climatic regions was correlated with their phenology.

We made the following assumptions prior to the analyses of our data to facilitate the comparability of our trials. (1) At Anykčiai, we used growth data after the 3rd growing season to avoid the effect of fertilization applied in this particular trial at the beginning of the 4th growing season. However, we still used the phenology screened at age 4 assuming the positive correlation of the same phenology variables between different years $[26,27]$. (2) At Tierp, the measurements and observations from the blocks 3 and 4 were used for statistical analyses of growth and phenology. The trees in blocks 1 and 2 were heavily damaged by extensive vole populations (Microtus agrestis and Arvicola terrestris), which significantly affected growth of the trees in these two blocks and were therefore excluded from the statistical analyses. (3) At Bodarna, we used 7th year growth for statistical analysis, as the mean size of the trees on this clayey site was comparable to the 4 th year growth at the other five sites on sandy loam, indicating that competition between the trees in all trials was similar (Table 4). (4) At Bodarna, bud burst was scored in the beginning of the 10th growing season, assuming it to be positively correlated with the bud burst in earlier years [26, 27].

\section{Statistical analyses}

We used a quantitative genetic analysis to describe the variation in heritable traits. The analyses of the trials at Tierp, Ludza, Šašaičiai, and Anykščiai were based on single-tree plots, while at Bodarna and Arlösa, we analyzed the means of line plots. Means of the line plots were calculated to obtain a single value per block and genotype, which enabled us to compare Arlösa and Bodarna trials with single-tree plots in the other trials in this investigation. Variance components were derived using a restricted maximum likelihood procedure (REML) in a linear mixed model in SYSTAT Version 13. The analyses were undertaken separately for each trait and trial assuming that the genotypes were unrelated, with CLONE as random effect and BLOCK as the fixed categorical effect. The spatial variation in microenvironment was accounted for by the random effects of ROW and within 


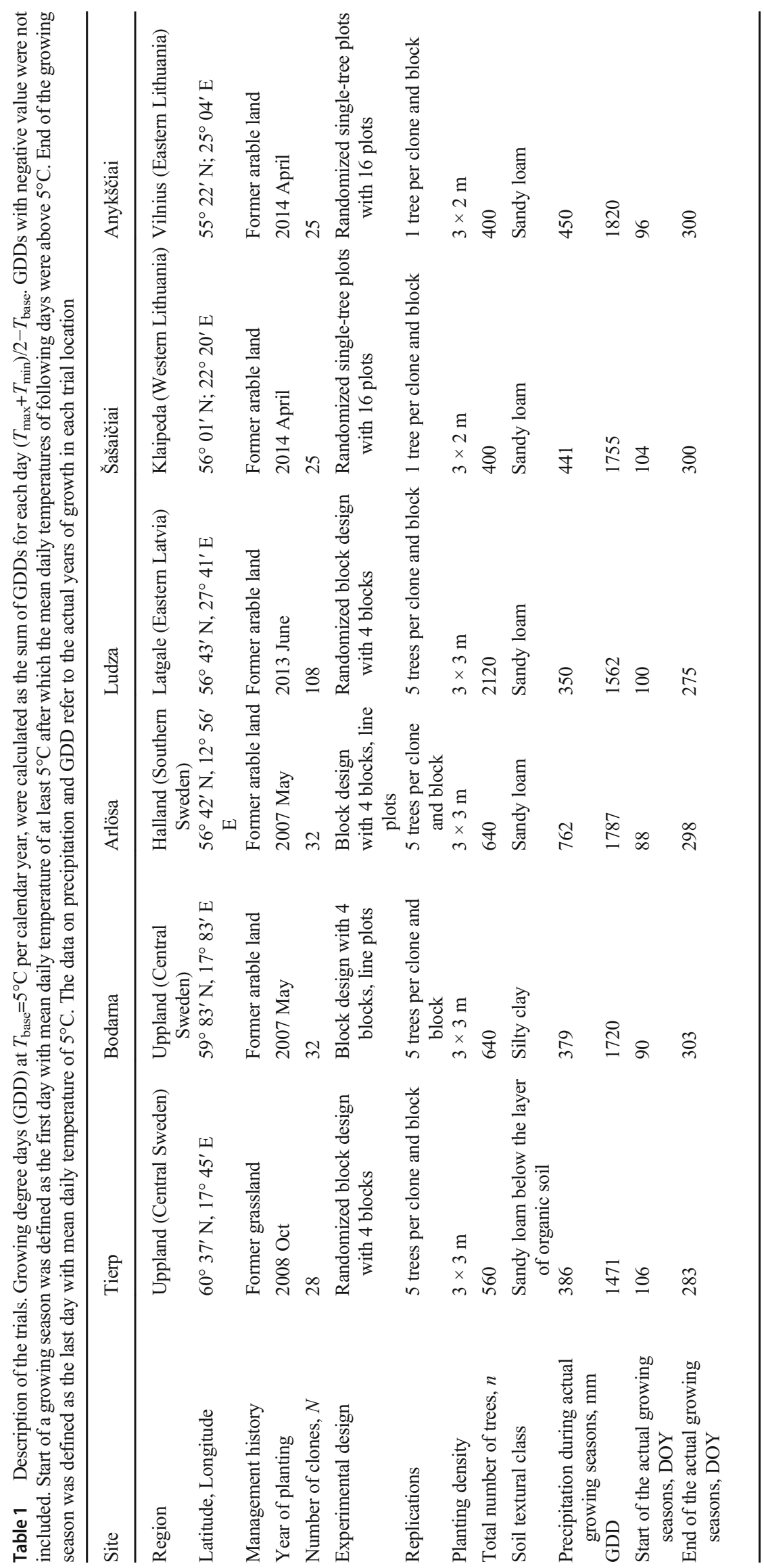




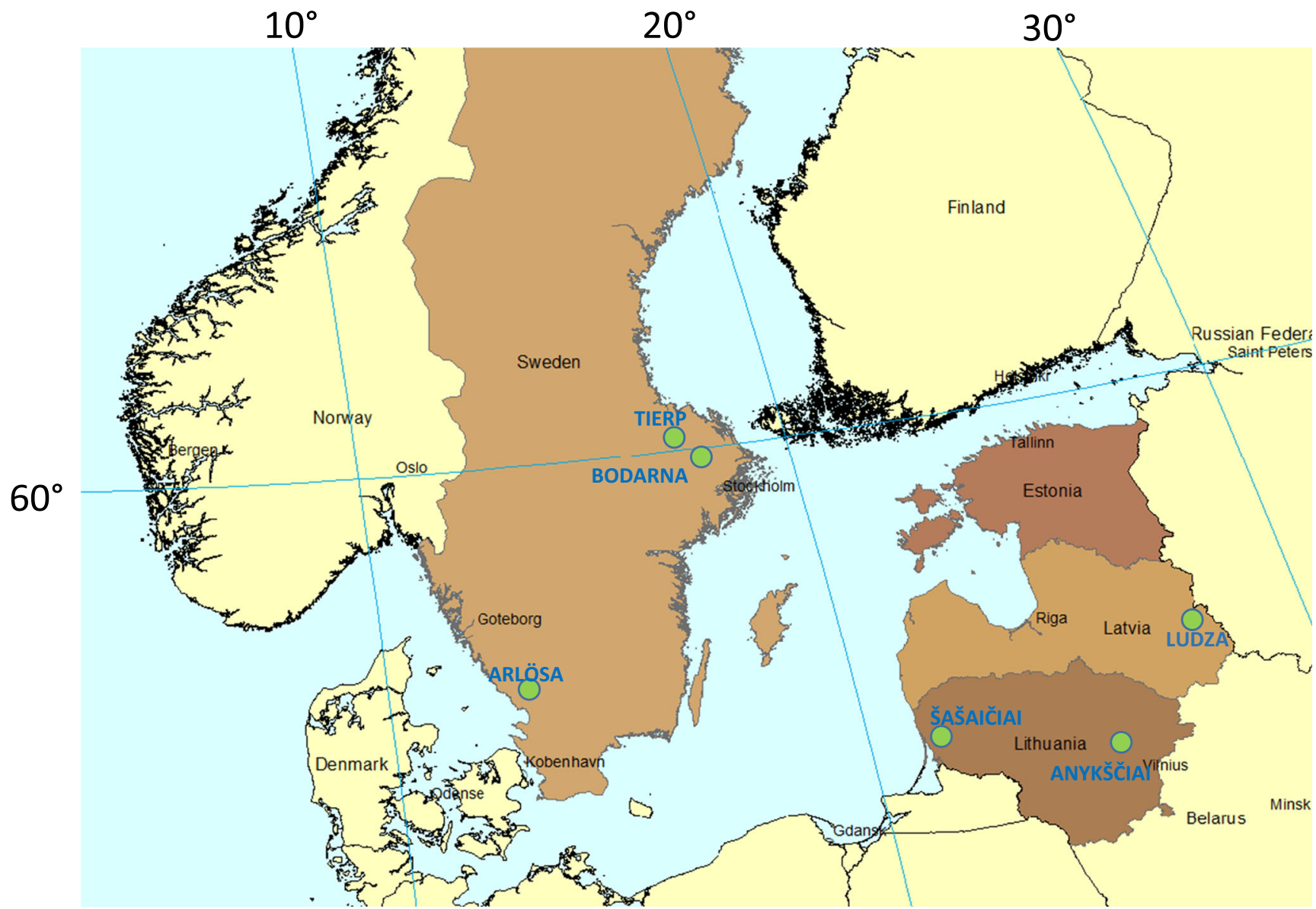

Fig. 1 Location of clonal trials with poplars in the Baltic Sea Region in Northern Europe between $55^{\circ}$ and $61^{\circ}$ of northern latitude and $12^{\circ}$ and $25^{\circ}$ of eastern longitude

row POSITION of a tree or line plot both nested within BLOCK. The values for volume index $\left(v_{i}\right)$ were logarithmically transformed prior to analysis. The clonal values for specific traits were calculated as the sum of mean trait value and the random effect predictions for individual clones (BLUPs (best linear unbiased predictions)) from the linear mixed model.

The broad-sense heritabilities of clonal values $\left(H_{c}^{2}\right)$ were calculated as a proportion of genotypic (clonal) variance component of total random variance:

$H_{\mathrm{c}}^{2}=\left(\sigma_{\mathrm{G}}^{2}\right) /\left(\sigma_{\mathrm{G}}^{2}+\sigma_{\mathrm{en}}^{2}\right)$

where $\sigma_{\mathrm{G}}^{2}$ is the variance component for the random effect CLONE and $\sigma_{\text {en }}^{2}$ is the environment-related variance component calculated as the sum of spatial variance and residual variance as

$\sigma_{\text {en }}^{2}=\sigma_{\text {spatial }}^{2}+\sigma_{\mathrm{e}}^{2}$

The repeatability of predicted clonal mean values $\left(R_{\mathrm{G}}^{2}\right)$ was calculated as
$R_{\mathrm{G}}^{2}=\left(\sigma_{\mathrm{G}}^{2}\right) /\left(\sigma_{\mathrm{G}}^{2}+\sigma_{\mathrm{en}}^{2} / k\right)$

where $\sigma_{\mathrm{G}}^{2}$ and $\sigma_{\mathrm{en}}^{2}$ denote the genotypic and environmental component of variance as in equation 1 and $k$ is the harmonic mean number of replications per clone. The standard errors for repeatability estimates were calculated based on the formula for unequal number of observations [28]:

$S E\left(R_{G}^{2}\right)=\sqrt{\frac{2(n-1)\left(1-R_{G}^{2}\right)^{2}\left[1+(k-1) R_{G}^{2}\right]^{2}}{k^{2}(n-N)(N-1)}}$

where $N$ is the number of clones tested and $n$ is the total number of individual values. The coefficients of genotypic, environmental, and phenotypic variances were calculated as

$C V_{\mathrm{G}}=\sigma_{\mathrm{G}} \times 100 / \mu$

$C V_{\text {en }}=\sigma_{\text {en }} \times 100 / \mu$

$C V_{\mathrm{ph}}=\sigma_{\mathrm{ph}} \times 100 / \mu$

where $\sigma_{G}, \sigma_{e n}$, and $\sigma_{p h}$ denote genotypic, environmental, and phenotypic standard deviation and $\mu$ is the phenotypic mean of the trait. 
Table 2 Number of tested Populus clones per trial and species/hybrid in current study. The provenance hybrids of $P$. trichocarpa bred at Swedish University of Agricultural Sciences are denoted as $\mathrm{T} \times \mathrm{T}_{\mathrm{SLU}}$. Clones derived from selected individuals from natural populations of $P$. trichocarpa and P. balsamifera in British Columbia, are indicated as $\mathrm{T}$ and $\mathrm{B}$, respectively. Among reference clones from Central Europe are several commercial hybrids of $P$. maximowiczii $\times P$. trichocarpa $(\mathrm{M} \times \mathrm{T})$,

\begin{tabular}{|c|c|c|c|c|c|c|}
\hline \multirow[t]{2}{*}{ Species groups } & \multicolumn{6}{|l|}{ Trials } \\
\hline & Tierp & Bodarna & Arlösa & Ludza & Šašaičiai & Anykščiai \\
\hline 1. P. trichocarpa $\times$ P. trichocarpa clones bred for northern latitudes, $\mathrm{T} \times \mathrm{T}_{\mathrm{SLU}}$ & 8 & 8 & 6 & 74 & 11 & 11 \\
\hline 2. P. trichocarpa, $\mathrm{T}$ & 16 & 20 & 17 & 22 & & \\
\hline 3. P. balsamifera, B & 1 & 2 & 2 & & & \\
\hline \multicolumn{7}{|l|}{ 4. Reference clones } \\
\hline $\mathrm{M} \times \mathrm{T}_{(\mathrm{OP} 42 .}$ Hybrid 275. OP41, Matrix24; Matrix49) & 2 & 2 & 2 & 2 & 4 & 4 \\
\hline $\mathrm{N} \times \mathrm{M}_{(\operatorname{Max} 1 ; \operatorname{Max} 3 ; \operatorname{Max} 4)}$ & & & & & 3 & 3 \\
\hline $\mathrm{N} \times \mathrm{D}(\mathrm{AF} 3 ; \mathrm{AF} 6 ; \mathrm{AF7} ; \mathrm{AF} 13 ; \mathrm{AF} 34)$ & & & & & 5 & 5 \\
\hline $\mathrm{T} \times \mathrm{D}_{(70.045 / 1 ; 69.037 / 2 ; 78.026 / 12)}$ & & & 2 & 2 & 1 & 1 \\
\hline $\mathrm{T} \times \mathrm{T}_{\mathrm{REF}}(\mathrm{S} .192-5 * \mathrm{~V} 24 / 12 ; 70.038 / 20 ; 70.038 / 67 ; 240)$ & 1 & & 3 & 4 & 1 & 1 \\
\hline $\mathrm{T}_{\mathrm{REF}(1559 ; \text { Spirit })}$ & & & & 2 & & \\
\hline$P$. tremula $\times P$. tremuloides & & & & 2 & & \\
\hline
\end{tabular}

$P$. nigra $\times P$. maximowiczii $(\mathrm{N} \times \mathrm{M}), P$. nigra $\times P$. deltoides $(\mathrm{N} \times \mathrm{D})$. The $P$. trichocarpa $\times P$. deltoides $(\mathrm{T} \times \mathrm{D})$ and $P$. trichocarpa $\times P$. trichocarpa $\left(\mathrm{T} \times \mathrm{T}_{\mathrm{REF}}\right)$ hybrids are originally from a poplar breeding program at INBO in Belgium. The reference clones of $P$. trichocarpa are of unknown origin $\left(\mathrm{T}_{\mathrm{REF}}\right)$. The $P$. tremula $\times P$. tremuloides hybrids are from a breeding program at Latvian Forest Research Institute SILAVA
Genotypic correlations between the different traits within the same trials were estimated using Spearman rank correlation analysis.

The genotype $\times$ environment $(\mathrm{G} \times \mathrm{E})$ interactions were analyzed through type B genotypic correlations [29, 30] of the same trait between pairs of trials. New genotypic values (BLUPs) were calculated for each pair of trials including only common clones in these pairs. The type B genotypic correlations were estimated as [31]:

$r_{G x y}=r_{x y} /\left(r_{T P x} \times r_{T P y}\right)$

where $r_{x y}$ is the product-moment correlation between best linear 
Table 4 The phenotypic mean of tree growth traits of all Populus clones at six trials in Northern Europe $(\mu)$, range of variation and coefficient of phenotypic variance $\left(\mathrm{CV}_{\mathrm{ph} ;} \%\right)$ of the measured and observed characteristics. $s$, survival; $d b h$, diameter at breast height (mm); $h$, tree height $(\mathrm{dm})$; $B B R$, bud burst; $v_{i}$ volume index; $B$ Set, bud set; $n$, number of observations (trees). The number after the abbreviations denotes age of the trees at the time of inventory

\begin{tabular}{|c|c|c|c|c|c|}
\hline Trait & Site & $n$ & $\begin{array}{l}\text { Mean }(\mu) \pm \\
\text { SE }\end{array}$ & $\begin{array}{l}\text { Range (min-- } \\
\max )\end{array}$ & $\begin{array}{l}\mathrm{CV}_{\mathrm{ph}} \\
(\%)\end{array}$ \\
\hline \multirow[t]{6}{*}{ Survival, $s$} & Tierp, $s_{4}$ & 405 & $0.75 \pm 0.02$ & $0.0-1.0$ & 55.5 \\
\hline & Bodarna, $s_{5}$ & 128 & $0.73 \pm 0.03$ & $0.0-1.0$ & 41.8 \\
\hline & Arlösa, $s_{3}$ & 128 & $0.94 \pm 0.01$ & $0.2-1.0$ & 15.8 \\
\hline & Ludza, $s_{4}$ & 2088 & $0.99 \pm 0.003$ & $0.0-1.0$ & 12.0 \\
\hline & Šašaičiai, $s_{4}$ & 374 & $0.84 \pm 0.02$ & $0.0-1.0$ & 43.5 \\
\hline & Anykščiai, $s_{4}$ & 373 & $0.88 \pm 0.02$ & $0.0-1.0$ & 34.0 \\
\hline \multirow[t]{6}{*}{ Diameter, $d b h(\mathrm{~mm})$} & Tierp, $d b h_{4}$ & 136 & $29.51 \pm 0.86$ & $7.5-56.0$ & 33.2 \\
\hline & Bodarna, $d b h_{7}$ & 126 & $24.63 \pm 1.29$ & $3.0-80.0$ & 54.1 \\
\hline & Arlösa, $d b h_{4}$ & 124 & $36.43 \pm 1.23$ & $7.9-73.5$ & 37.8 \\
\hline & Ludza, $d b h_{4}$ & 2038 & $28.63 \pm 0.24$ & $3.0-68.0$ & 38.0 \\
\hline & Šašaičiai, $d b h_{4}$ & 311 & $23.09 \pm 0.53$ & $3.0-61.0$ & 40.9 \\
\hline & Anykščiai, $d b h_{3}$ & 263 & $24.73 \pm 0.63$ & $5.0-55.0$ & 35.1 \\
\hline \multirow[t]{6}{*}{ Height, $h(\mathrm{dm})$} & Tierp, $h_{4}$ & 135 & $32.47 \pm 0.85$ & $7.0-61.0$ & 29.9 \\
\hline & Bodarna, $h_{7}$ & 126 & $34.30 \pm 1.16$ & $13.5-88.2$ & 35.0 \\
\hline & Arlösa, $h_{4}$ & 124 & $43.77 \pm 1.04$ & $17.6-69.0$ & 26.0 \\
\hline & Ludza, $h_{4}$ & 2037 & $42.93 \pm 0.22$ & $9.2-72.8$ & 22.7 \\
\hline & Šašaičiai, $h_{4}$ & 315 & $31.10 \pm 0.47$ & $10.0-55.4$ & 25.4 \\
\hline & Anykščiai, $h_{3}$ & 263 & $29.78 \pm 0.48$ & $14.0-53.0$ & 22.2 \\
\hline \multirow{6}{*}{$\begin{array}{l}\text { Volume index, } v_{i} \\
\qquad\left(\mathrm{dm}^{3}\right)\end{array}$} & Tierp, $v_{i 4}$ & 135 & $3.72 \pm 0.30$ & $0.04-19.13$ & 92.3 \\
\hline & Bodarna, $v_{i 7}$ & 126 & $4.07 \pm 0.71$ & $0.01-48.90$ & 69.7 \\
\hline & Arlösa, $v_{i 4}$ & 124 & $7.78 \pm 0.67$ & $0.11-35.52$ & 98.7 \\
\hline & Ludza, $v_{i 4}$ & 2037 & $4.63 \pm 0.10$ & $0.01-29.41$ & 61.1 \\
\hline & Šašaičiai, $v_{i 4}$ & 311 & $2.25 \pm 0.13$ & $0.01-20.61$ & 97.5 \\
\hline & Anykščiai, $v_{i 3}$ & 263 & $2.53 \pm 0.17$ & $0.04-14.82$ & 91.5 \\
\hline \multirow[t]{8}{*}{ Bud burst (score) } & Tierp $\left(B B R_{2}\right.$ - date $\left.10 / 04 / 15\right)$ & 129 & $1.52 \pm 0.04$ & $1.0-2.0$ & 33.6 \\
\hline & $\begin{array}{l}\text { Bodarna }\left(B B R_{10} \text { - date }\right. \\
\text { 19/04/26) }\end{array}$ & 120 & $4.10 \pm 0.08$ & $2.0-5.0$ & 22.6 \\
\hline & $\begin{array}{l}\text { Arlösa }\left(B B R_{4} \text { - date }\right. \\
10 / 04 / 16)\end{array}$ & 124 & $3.73 \pm 0.06$ & $2.0-5.0$ & 17.4 \\
\hline & $\begin{array}{c}\text { Arlösa }\left(B B R_{4} \text { - date }\right. \\
10 / 04 / 27)\end{array}$ & 124 & $4.88 \pm 0.03$ & $3.3-5.0$ & 6.6 \\
\hline & $\begin{array}{l}\text { Ludza }\left(B B R_{3} \text { 一 date }\right. \\
15 / 04 / 22)\end{array}$ & 2038 & $2.41 \pm 0.01$ & $0.0-5.0$ & 25.1 \\
\hline & $\begin{array}{l}\text { Šašaičiai }\left(B B R_{4} \text { - date }\right. \\
\text { 17/04/27) }\end{array}$ & 312 & $2.51 \pm 0.04$ & $1.0-3.5$ & 30.2 \\
\hline & $\begin{array}{l}\text { Anykščiai }\left(B B R_{4} \text { — date }\right. \\
17 / 04 / 28)\end{array}$ & 263 & $3.04 \pm 0.05$ & $1.5-4.0$ & 30.3 \\
\hline & $\begin{array}{l}\text { Anykščiai }\left(B B R_{4} \text { - date }\right. \\
\text { 17/04/14) }\end{array}$ & 263 & $2.28 \pm 0.04$ & $1.0-3.0$ & 29.7 \\
\hline \multirow[t]{3}{*}{ Bud set (score) } & $\begin{array}{l}\text { Ludza }\left(B B t_{4} \text { - date }\right. \\
16 / 09 / 15)\end{array}$ & 1003 & $0.16 \pm 0.01$ & $0.0-4.0$ & 192.5 \\
\hline & $\begin{array}{l}\text { Šašaičiai }\left(B S e t_{4} \text { —date }\right. \\
\text { 17/09/16) }\end{array}$ & 315 & $0.59 \pm 0.04$ & $0.0-2.0$ & 113.7 \\
\hline & $\begin{array}{l}\text { Anykščiai }\left(\mathrm{BSet}_{4} \text { — date }\right. \\
17 / 09 / 15)\end{array}$ & 247 & $0.74 \pm 0.05$ & $0.0-3.0$ & 102.4 \\
\hline
\end{tabular}

\section{Results}

Mean height $h$ of the trees varied between 3 and $4.4 \mathrm{~m}$, mean $d b h$ had values between 23 and $36 \mathrm{~mm}$, and mean $v_{i}$ was 2.3 to $7.8 \mathrm{dm}^{3}$. Bud burst had mean values between 1.52 in Tierp and 4.88 in Arlösa. Mean score for bud set was between 0.16 and 0.74 in the three Baltic trials (Table 4). It is important to note here that all clonal trials in this study, except the two Lithuanian trials, had different compositions of poplar clones (Table 2), which is the reason why we test our main 
hypothesis within each trial separately. Using only common clones for pairwise comparison of trials allowed identification of genotype-by-environment interactions $(\mathrm{G} \times \mathrm{E})$.

\section{Substantial clonal variation and significant correlations between phenology and growth at early ages}

Plant survival varied from $73 \%$ at Bodarna to $99 \%$ at Ludza, and there were no clonal differences in survival in the four northernmost trials (S2-S5). In contrast, significantly lower survival was recorded for several $P$. nigra $\times$ P. deltoides $(\mathrm{N} \times \mathrm{D})$ hybrids compared to the mean survival in the Lithuanian trials, which was $84-88 \%$ (S6-S7). These $\mathrm{N} \times \mathrm{D}$ hybrids were included among the tested clones only in the Lithuanian trials.

The broad-sense heritability estimates $\left(H_{c}^{2}\right)$ for growth variables $\left(d b h, h, v_{i}\right)$, which were expressed as the ratio of genotypic to total variance, varied from 0.22 to 0.79 (Table 5). The highest $H_{c}^{2}$ estimates were at Arlösa (between 0.75 and 0.79 ), while in the rest of the trials $H_{c}^{2}$ varied between 0.22 and 0.43 . In all other trials, the heritabilities, i.e., variance related to clone, explained between 22.2 and $42.9 \%$ of the total variance in volume index $v_{i}$, with corresponding heritabilities from 0.22 to 0.43 (Table 5).

The broad-sense heritability $\left(H_{c}^{2}\right)$ of bud burst had high values in all the trials (from 0.88 to 0.90 ), except at Tierp (0.42, Table 5). Bud set, which was scored only in Baltic trials, occurred earlier at Ludza (Latvia, $H_{c}^{2}=0.31$ ) than at both Lithuanian trials $\left(H_{c}^{2}=0.76-0.83\right.$, Table 5 ; S5-S7).

The coefficient of genotypic variance $\left(C V_{G}\right)$ was moderate for bud burst and growth, ranging from 6.2 to 31.0 for bud burst, 12.5 to 23.0 for $h, 16.8$ to 33.7 for $d b h$, and 4.6 to 8.7 for $v_{i}$ (Table 5). The $C V_{G}$ of bud set ranged from 89.4 to 107.6, indicating a large genetic variance among the tested clones (Table 5). Bud burst was positively correlated with growth in both Lithuanian trials, where clones with earlier bud burst had better growth in terms of volume index or height, respectively $(r=$ 0.46 at $p<0.05$ at Šašaičiai; $r=0.42-0.51$ at $p<0.05$ at Anykščiai and Šašaičiai; Table 6; Fig. 2). In contrast, clones with late spring phenology in relation to the trial mean, had better growth in diameter, $d b h$, at Bodarna (Table 6; Fig. 2). A positive correlation between late bud set and growth was found at Ludza for all the observed growth variables and at Anykščiai for height $(r=0.42-0.50$ at $p<0.05$; Table 6; Fig. 3). Bud burst and bud set within the trials where both spring and autumn phenology were inventoried, were not correlated (Table 6).

\section{Genotype-by-environment interaction as a base for delineation of breeding zones}

Pairwise comparison of common clones revealed that their ranking according to volume index $v_{i}$ did not change significantly between the Swedish trials, Arlösa and Bodarna $\left(r_{\mathrm{Gxy}}=0.80\right.$ at $p<0.0001$; Table 7$)$ and between Arlösa and Tierp $\left(r_{\mathrm{Gxy}}=0.66\right.$ at $p<0.005$; Table 7$)$. Note that significant positive correlations between ranks indicate no $\mathrm{G} \times \mathrm{E}$ interaction in terms of early growth. In contrast, rankings of clones according to their bud burst were different at Tierp compared to Arlösa $\left(r_{\mathrm{Gxy}}=0.36, p=\mathrm{ns}\right)$ and Bodarna $\left(r_{\mathrm{Gxy}}=0.50, p=\right.$ $\mathrm{ns})$, which indicates a $\mathrm{G} \times \mathrm{E}$ interaction (Table 7). Moreover, the ranking shifts occurred both in volume index $v_{i}$ and bud burst in the Bodarna-Tierp pair indicating a $\mathrm{G} \times \mathrm{E}$ interaction (Table 7). These interactions reveal that top-performing clones at Tierp are different from those at Bodarna and Arlösa. The relative rankings of clones according to $v_{i}$ and spring phenology in the pairs Bodarna-Ludza and Arlösa-Ludza did not change, indicating a common breeding zone for central and southern Sweden as well as for Latvia.

The relative ranking of clones according to their phenology did not change at Šašaičiai-Ludza and Anykščiai-Šašaičiai (significant correlations $r_{G x y}=0.82$ at $p<0.05$ and $r_{G x y}=$ 0.98 at $p<0.0001$ for $B B R$ and $r_{G x y}=0.87$ at $p<0.05$ and $r_{G x y}=0.92$ at $p<0.0001$ for $B S e t$, respectively), while ranking of clones according to their volume index $v_{i}$ was not correlated (Table 7). As the rankings of common clones in the pair Anykščiai-Ludza changed in terms of both growth and phenology (Table 7), the Anykščiai region (eastern Lithuania) outlines as a separate breeding zone for poplars in the studied region. Moreover, the correlation coefficient for volume index $v_{i}$ in this pair of trials was negative, meaning that top clones at Ludza, eastern Latvia, had modest growth performance at Anykščiai in eastern Lithuania (Table 7).

\section{Early selection of poplar clones for commercial deployment in Northern Europe}

We used volume index $v_{i}$ after 3-4 years' growth of poplars on sandy loam soils for ranking of examined clones, while the clones at the Bodarna trial on silty clay were ranked after 7 years' growth (Figs. 4 and 5). The provenance hybrids of $P$. trichocarpa had significantly higher clonal values for $v_{i}$ compared to the trial mean (i.e., were top-ranked) in the northernmost trial, at Tierp, where the sum of growing degree days was lowest, 1471, in the current study (Table 1, Figs. 4 and 5, S2). The top-ranked clones had late or intermediate bud burst (S2) in relation to the trial mean (Table 4).

Both provenance hybrids of $P$. trichocarpa $\left(\mathrm{T} \times \mathrm{T}_{\mathrm{SLU}}\right)$ and the hybrids between $P$. maximowiczii and $P$. trichocarpa $(\mathrm{M} \times \mathrm{T})$ were among the top-ranked clones in southern and central Sweden, Latvia, and western Lithuania, where the sum of growing degree days was above 1562-1787 (Table 1, Figs. 4 and 5, S3-S6).

In contrast, hybrids with a $P$. nigra parent or a $P$. maximowiczii parent were among the best performing clones in the southernmost site at Anykščiai (eastern 
Table 5 Results from the mixed linear model analysis of growth and adaptive traits of poplar clones at age of 3-4 years at five sites around the Baltic Sea and at age 7 years in Bodarna. $\sigma_{G}^{2}$, clonal variance component, which corresponds to broad-sense heritability as a percent of the total

\begin{tabular}{|c|c|c|c|c|c|c|c|c|}
\hline Trait & Site & $H_{c}^{2}$ & $\sigma_{\mathrm{G}}^{2}(\%)$ & $\sigma_{\text {spatial }}^{2}(\%)$ & $\sigma_{\mathrm{e}}^{2}(\%)$ & $\mathrm{R}_{\mathrm{G}}^{2} \pm \mathrm{SE}$ & $\mathrm{CV}_{\mathrm{G}}(\%)$ & $\mathrm{CV}_{\text {en }}(\%)$ \\
\hline$d b h_{4}$ & Tierp & 0.43 & 42.9 & 22.1 & 35.0 & $0.57 \pm 0.09$ & 21.8 & 25.1 \\
\hline$h_{4}$ & Tierp & 0.42 & 42.2 & 17.0 & 40.8 & $0.59 \pm 0.09$ & 19.4 & 22.8 \\
\hline$v_{i 4}$ & Tierp & 0.43 & 42.9 & 17.2 & 39.9 & $0.60 \pm 0.09$ & 6.1 & 9.3 \\
\hline$B B R_{2}$ - date 20100415 & Tierp & 0.42 & 41.5 & 4.6 & 53.9 & $0.68 \pm 0.08$ & 21.6 & 25.7 \\
\hline$s_{4}$ & Tierp & 0.02 & 1.7 & 9.8 & 88.4 & $0.08 \pm 0.05$ & 7.3 & 55.0 \\
\hline$d b h_{7}$ & Bodarna & 0.35 & 35.1 & 37.1 & 27.8 & $0.44 \pm 0.10$ & 32.0 & 43.6 \\
\hline$h_{7}$ & Bodarna & 0.37 & 37.2 & 38.0 & 24.8 & $0.46 \pm 0.09$ & 21.3 & 27.7 \\
\hline$v_{i 7}$ & Bodarna & 0.35 & 35.3 & 25.6 & 39.1 & $0.50 \pm 0.09$ & 9.2 & 12.5 \\
\hline$B B R_{10}$ - date 20190426 & Bodarna & 0.88 & 88.0 & 0.9 & 11.1 & $0.97 \pm 0.01$ & 31.0 & 11.5 \\
\hline$s_{5}$ & Bodarna & 0.12 & 11.8 & 32.3 & 55.9 & $0.20 \pm 0.09$ & 14.4 & 39.2 \\
\hline$d b h_{4}$ & Arlösa & 0.79 & 79.3 & 9.1 & 11.6 & $0.94 \pm 0.02$ & 33.7 & 17.2 \\
\hline$h_{4}$ & Arlösa & 0.78 & 78.0 & 11.5 & 10.5 & $0.93 \pm 0.02$ & 23.0 & 12.2 \\
\hline$v_{i 4}$ & Arlösa & 0.75 & 75.2 & 9.9 & 14.9 & $0.92 \pm 0.02$ & 8.7 & 5.0 \\
\hline$B B R_{4}$ - date 20100416 & Arlösa & 0.91 & 91.0 & 0.2 & 9.0 & $0.97 \pm 0.01$ & 16.6 & 5.3 \\
\hline$B B R_{4}$-date 20100427 & Arlösa & 0.88 & 88.4 & 1.9 & 11.4 & $0.96 \pm 0.01$ & 6.2 & 2.4 \\
\hline$s_{3}$ & Arlösa & 0 & 0.00 & 32.8 & 68.2 & $0.00 \pm 0.07$ & 0.0 & 15.8 \\
\hline$d b h_{4}$ & Ludza & 0.28 & 27.6 & 15.7 & 56.7 & $0.60 \pm 0.04$ & 20.0 & 32.3 \\
\hline$h_{4}$ & Ludza & 0.30 & 30.2 & 15.9 & 53.8 & $0.62 \pm 0.03$ & 12.5 & 19.0 \\
\hline$v_{i 4}$ & Ludza & 0.27 & 27.1 & 14.6 & 58.3 & $0.60 \pm 0.03$ & 5.8 & 9.5 \\
\hline$B B R_{3}$ - date 20150422 & Ludza & 0.68 & 67.7 & 0.6 & 31.8 & $0.97 \pm 0.001$ & 20.6 & 14.3 \\
\hline $\mathrm{BSet}_{4}$-date 20160915 & Ludza & 0.31 & 31.3 & 9.4 & 59.4 & $0.66 \pm 0.03$ & 107.6 & 159.6 \\
\hline$s_{4}$ & Ludza & 0 & 0.00 & 0.0 & 100.0 & $0.00 \pm 0.01$ & 0.0 & 12.0 \\
\hline$d b h_{4}$ & Šašaičiai & 0.28 & 27.5 & 13.0 & 59.6 & $0.60 \pm 0.08$ & 21.4 & 34.9 \\
\hline$h_{4}$ & Šašaičiai & 0.32 & 32.0 & 18.8 & 49.3 & $0.58 \pm 0.08$ & 15.2 & 22.1 \\
\hline$v_{i 4}$ & Šašaičiai & 0.35 & 35.2 & 9.7 & 55.2 & $0.70 \pm 0.07$ & 8.02 & 10.9 \\
\hline$B B R_{4}$-date 20170427 & Šašaičiai & 0.91 & 91.3 & 0.9 & 7.8 & $0.98 \pm 0.01$ & 28.9 & 8.9 \\
\hline BSet $_{4}$-date 20170916 & Šašaičiai & 0.83 & 83.1 & 2.0 & 14.9 & $0.96 \pm 0.01$ & 103.6 & 46.7 \\
\hline$s_{4}$ & Šašaičiai & 0.28 & 27.6 & 3.0 & 69.4 & $0.78 \pm 0.05$ & 22.5 & 43.5 \\
\hline$d b h_{3}$ & Anykščiai & 0.23 & 22.9 & 15.3 & 61.9 & $0.51 \pm 0.08$ & 16.8 & 30.8 \\
\hline$h_{3}$ & Anykščiai & 0.32 & 32.2 & 11.3 & 56.6 & $0.65 \pm 0.07$ & 12.6 & 18.3 \\
\hline$v_{i 3}$ & Anykščiai & 0.22 & 22.2 & 120 & 65.9 & $0.54 \pm 0.08$ & 4.6 & 8.7 \\
\hline$B B R_{4}$ —date 20170414 & Anykščiai & 0.86 & 86.0 & 1.3 & 12.7 & $0.97 \pm 0.01$ & 27.5 & 11.1 \\
\hline$B B R_{4}$-date 20170428 & Anykščiai & 0.90 & 89.9 & 1.7 & 8.5 & $0.97 \pm 0.01$ & 28.7 & 9.6 \\
\hline $\mathrm{BSet}_{4}$ —date 20170915 & Anykščiai & 0.76 & 76.3 & 2.8 & 20.9 & $0.94 \pm 0.02$ & 89.4 & 49.9 \\
\hline$s_{4}$ & Anykščiai & 0.14 & 13.5 & 7.7 & 78.9 & $0.51 \pm 0.08$ & 13.4 & 34.0 \\
\hline
\end{tabular}

random variance; $\sigma_{\text {spatial }}{ }^{2}$, spatial variance component; $\sigma_{e}{ }^{2}$, residual variance component; $R_{G}{ }^{2}$, repeatability of clonal means; $C V_{G}$, coefficient of genotypic variation; $C V_{e n}$, coefficient of environmental variation 
Table 6 Genotypic correlations among growth and adaptive traits of hybrid poplar clones at individual trials after 3-4 years of growth at Tierp, Arlösa, Ludza, Šašaičiai, and Anykščiai (sandy loam) and after 7 years of growth at Bodarna (silty clay). The number after the abbreviations denotes the age of the trees at the time of inventory, e.g., $h_{4}=$ height at 4 years. Correlations are significant at $p<0.05(*), p<0.005(* *)$, or $p<$ $0.0001(* * *)$

\begin{tabular}{|c|c|c|c|c|c|c|}
\hline Trait & Tree height, $h$ & Stem volume index, $v_{i}$ & Bud burst, $B B R$ & & Bud set, $B S e t$ & Survival, $s$ \\
\hline \multicolumn{7}{|l|}{ Tierp. central Sweden } \\
\hline$d b h_{4}$ & $0.86^{* * *}$ & $0.95 * * *$ & -0.10 & & & 0.09 \\
\hline$h_{4}$ & & $0.89 * * *$ & -0.15 & & & 0.07 \\
\hline$v_{i 4}$ & & & -0.12 & & & 0.1 \\
\hline$B B R_{2}$ 一 date $2010 / 04 / 15$ & & & & & & -0.25 \\
\hline \multicolumn{7}{|l|}{ Bodarna. central Sweden } \\
\hline$d b h_{7}$ & $0.97 * * *$ & $0.88 * * *$ & $-0.40 *$ & & & $0.68 * * *$ \\
\hline$h_{7}$ & & $0.88 * * *$ & $-0.35^{*}$ & & & $0.70 * * *$ \\
\hline$v_{i 7}$ & & & -0.32 & & & $0.55^{*}$ \\
\hline$B B R_{10}$ - date 20190426 & & & & & & -0.05 \\
\hline Arlösa. south-west Sweden & & & Date $2010 / 04 / 16$ & Date $2010 / 04 / 27$ & & \\
\hline$d b h_{4}$ & $0.97 * * *$ & $0.98 * * *$ & -0.17 & -0.03 & & $0.97 * * *$ \\
\hline$h_{4}$ & & $0.96^{* * *}$ & -0.20 & -0.08 & & $1.00 * * *$ \\
\hline$v_{i 4}$ & & & -0.23 & -0.07 & & $0.96^{* * *}$ \\
\hline$B B R_{4}$ — date $2010 / 04 / 27$ & & & $0.69 * * *$ & & & -0.08 \\
\hline$B B R_{4}$ - date $2010 / 04 / 16$ & & & & & & -0.20 \\
\hline \multicolumn{7}{|l|}{ Ludza. eastern Latvia } \\
\hline$d b h_{4}$ & $0.95 * * *$ & $0.99 * * *$ & -0.12 & & $0.57 * * *$ & 0.03 \\
\hline$h_{4}$ & & $0.97 * * *$ & -0.13 & & $0.53 * * *$ & -0.02 \\
\hline$v_{i 4}$ & & & -0.14 & & $0.56 * * *$ & 0.00 \\
\hline$B B R_{3}$ - date $2015 / 04 / 22$ & & & & & -0.18 & -0.03 \\
\hline $\mathrm{BSet}_{4}$ - date 2016/09/15 & & & & & & 0.03 \\
\hline \multicolumn{7}{|l|}{ Šašaičiai. western Lithuania } \\
\hline$d b h_{4}$ & $0.90 * * *$ & $0.96^{* * * *}$ & $0.46^{*}$ & & -0.26 & $0.59 * *$ \\
\hline$h_{4}$ & & $0.93 * * *$ & $0.51 *$ & & -0.26 & $0.54 * *$ \\
\hline$v_{i 4}$ & & & $0.46^{*}$ & & -0.23 & $0.58 * *$ \\
\hline$B B R_{4}$ — date $2017 / 04 / 27$ & & & & & -0.22 & 0.28 \\
\hline $\mathrm{BSet}_{4}$ — date $2017 / 09 / 16$ & & & & & & $-0.43 *$ \\
\hline Anykščiai. eastern Lithuania & & & Date $2010 / 04 / 14$ & Date $2010 / 04 / 07$ & & \\
\hline$d b h_{3}$ & $0.89 * * *$ & $0.98 * * *$ & 0.30 & 0.36 & 0.31 & 0.07 \\
\hline$h_{3}$ & & $0.93 * * *$ & $0.42 *$ & $0.50 *$ & $0.42 *$ & -0.09 \\
\hline$v_{i 3}$ & & & 0.38 & $0.44 *$ & 0.34 & -0.006 \\
\hline$B B R_{4}$ — date $2017 / 04 / 14$ & & & & $0.96 * * *$ & -0.09 & -0.05 \\
\hline$B B R_{4}$ 一 date $2017 / 04 / 28$ & & & $0.95 * * *$ & $0.93 * * *$ & -0.19 & 0.03 \\
\hline $\mathrm{BSet}_{4}$ - date $2017 / 09 / 15$ & & & -0.09 & -0.17 & & -0.23 \\
\hline
\end{tabular}

southern origin results in a relatively late bud set in relation to the place of origin and subsequently longer canopy duration $[12,16,32]$. The commercial deployment of southern clones at northern latitudes is an attractive strategy among landowners but is coupled with the risk for frost damage in the autumn as photoperiod-dependent bud set occurs in the north at daylengths when ambient temperatures are occasionally below zero. Similarly, spring leaf flush of southern clones at northern latitudes is likely to be delayed as temperature sums needed for bud burst occur several weeks after the growing season begins at northern latitudes. Genetic improvement of poplars for different climatic regions in Northern Europe would offer a possibility to increase the pool of renewable raw materials for circular economies and sustainable environments. A considerable genetic variation in growth and phenology traits is a prerequisite for genetic improvement by breeding. Here we studied phenotypic variation of growth and phenology of poplar clones with different origin to estimate the 

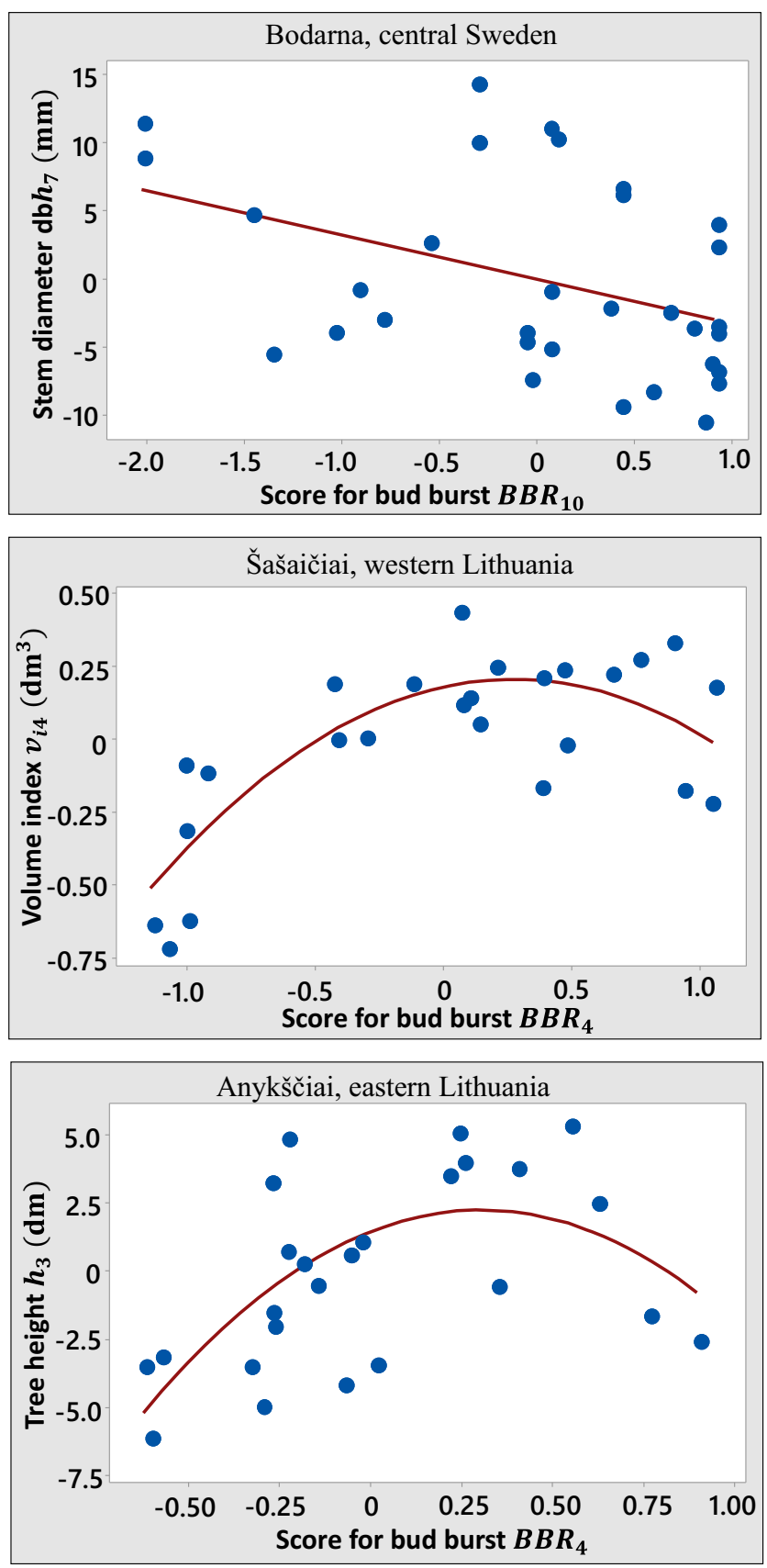

Fig. 2 Spearman correlation between BLUP values of score for bud burst $\left(B B R_{y r}\right)$ and growth at Bodarna, central Sweden $(r=-0.35$ at $p<0.05 ; N=$ 32), at Šašaičiai, western Lithuania $(r=0.51$ at $p<0.05 ; N=25)$ and at Anykščiai, eastern Lithuania $(r=0.46$ at $p<0.05 ; N=25)$

genotypic component of clonal variation in boreo-nemoral climates in Northern Europe [33-35]. We have shown that both bud burst and bud set have a significant effect on early growth of poplars in the Baltic Sea Region. The high heritability of phenology traits enables an early selection of locally adapted poplar clones with sufficient growth. We suggest three major breeding zones for poplar clones according to the pattern of the genotype-by-environment interactions of volume index and phenology in the Baltic Sea Region.
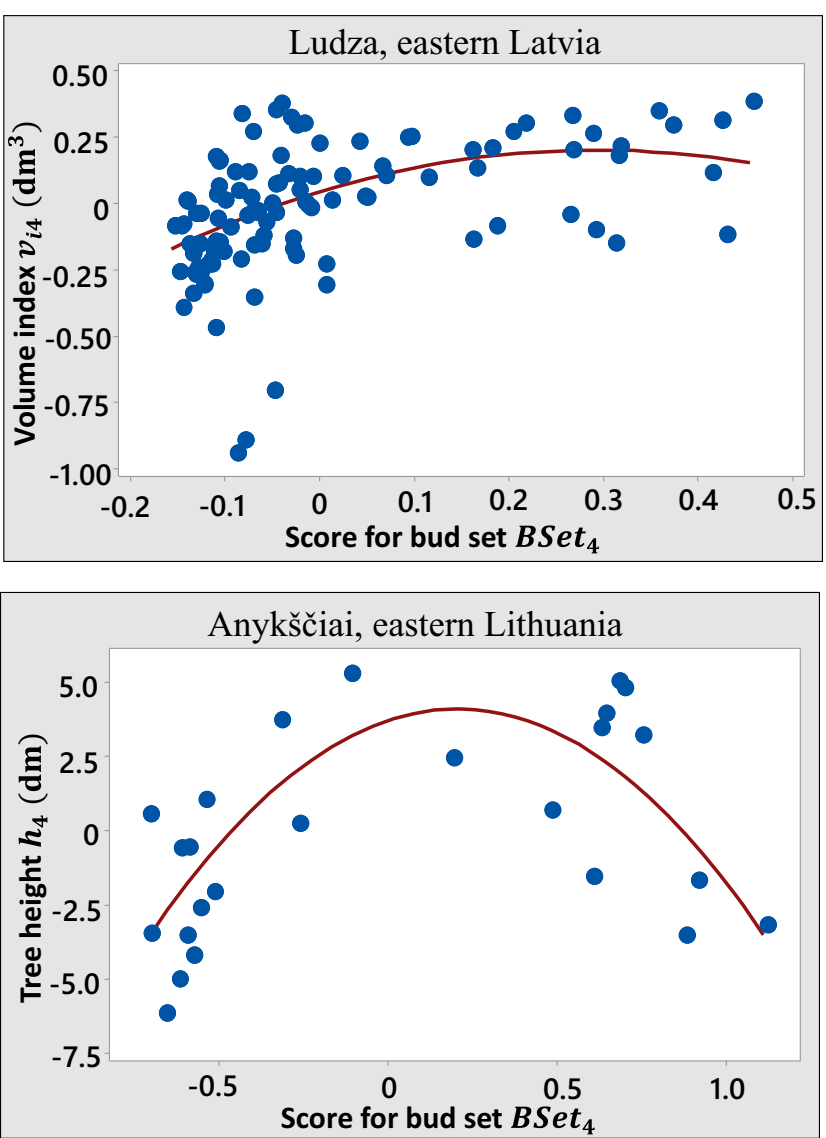

Fig. 3 Spearman correlation between BLUP values of score for bud set $\left(\mathrm{BSet}_{4}\right)$ and volume index $\left(v_{i 4}\right.$, log-transformed $)$ at Ludza, eastern Latvia $(r=0.56$ at $p<0.0001 ; N=108)$ or stem height at Anykščiai, eastern Lithuania $(r=0.50$ at $p<0.05 ; N=25)$

\section{Phenotypic and genotypic variations}

Considerable phenotypic and genotypic variation in growth and adaptive traits characterized the tested poplar material. We found that tree growth correlated significantly with spring or autumn phenology in all Baltic trials and in one trial in central Sweden at Bodarna. Significant negative correlation between early spring phenology and growth, measured as lifetime increment of stem diameter at breast height, was also reported by Richards et al. [36] who studied variation in the timing of leaf phenology at both ends of two growing seasons in a 14-15 years old poplar trial close to Bodarna in central Sweden. Although observations of bud set were not available for our Swedish trials, the significant effect of other leaf phenology traits on tree growth, such as leaf senescence and autumn leaf coloring, indicate that bud set may also have a significant effect on poplar growth in Swedish climates [37].

Clones with their origin from breeding programs for Central Europe, which were tested only in Šašaičiai and Anykščiai, showed mismatch to local growing conditions in the Lithuanian climate. For example, many of the P. nigra $\times$ $P$. deltoides $(\mathrm{N} \times \mathrm{D})$ hybrids with poor growth had late bud 
Table 7 Type B genotypic correlations $\left(r_{\mathrm{Gxy}}\right)$ of BLUPs for growth and adaptive traits between pairs of locations. Nonsignificant correlations indicate a genotype-by-environment interaction. The number after the abbreviations denotes age of the trees at the time of inventory

\begin{tabular}{|c|c|c|c|c|}
\hline Trial 1 & Trial 2 & $\begin{array}{l}\text { Number of common } \\
\text { clones, } N\end{array}$ & $r_{\mathrm{Gxy}}$ & $p$ \\
\hline \multicolumn{5}{|l|}{ Volume index, $v_{i}$} \\
\hline Arlösa, $v_{i 4}$ & Bodarna, $v_{i 7}$ & 27 & 0.80 & $<0.0001$ \\
\hline Arlösa, $v_{i 4}$ & Tierp, $v_{i 4}$ & 27 & 0.66 & $<0.005$ \\
\hline Bodarna, $v_{i 7}$ & Tierp, $v_{i 4}$ & 28 & 0.51 & Ns \\
\hline Arlösa, $v_{i 4}$ & Ludza, $v_{i 4}$ & 18 & 0.43 & Ns \\
\hline Bodarna, $v_{i 7}$ & Ludza, $v_{i 4}$ & 14 & 0.68 & Ns \\
\hline Anykščiai, $v_{i 3}$ & Ludza, $v_{i 4}$ & 11 & -0.46 & Ns \\
\hline Šašaičiai, $v_{i 4}$ & Ludza, $v_{i 4}$ & 11 & 0.25 & Ns \\
\hline Anykščiai, $v_{i 3}$ & Šašaičiai, $v_{i 3}$ & 25 & 0.40 & Ns \\
\hline \multicolumn{5}{|l|}{ Bud burst (date) } \\
\hline Arlösa, $B B R_{4}(2010 / 04 / 27)$ & $\begin{array}{l}\text { Bodarna, } B B R_{10} \\
\quad(2019 / 04 / 26)\end{array}$ & 27 & 0.68 & $<0.001$ \\
\hline Arlösa, $B B R_{4}(2010 / 04 / 27)$ & Tierp, $B B R_{2}(2010 / 04 / 15)$ & 25 & 0.36 & Ns \\
\hline $\begin{array}{l}\text { Bodarna, } B B R_{10} \\
\quad(2019 / 04 / 26)\end{array}$ & Tierp, $B B R_{2}(2010 / 04 / 15)$ & 28 & 0.50 & Ns \\
\hline Arlösa, $B B R_{4}(2010 / 04 / 27)$ & Ludza, $B B R_{3}(2015 / 04 / 22)$ & 18 & 0.61 & Ns \\
\hline $\begin{array}{l}\text { Bodarna, } B B R_{10} \\
\quad(2019 / 04 / 26)\end{array}$ & Ludza, $B B R_{3}(2015 / 04 / 22)$ & 14 & 0.59 & Ns \\
\hline $\begin{array}{l}\text { Anykščiai, } B B R_{4} \\
(2017 / 04 / 28)\end{array}$ & Ludza, $B B R_{3}(2015 / 04 / 22)$ & 11 & 0.82 & Ns \\
\hline $\begin{array}{l}\text { Šašaičiai, } B B R_{4} \\
\quad(2017 / 04 / 27)\end{array}$ & Ludza, $B B R_{3}(2015 / 04 / 22)$ & 11 & 0.82 & $<0.05$ \\
\hline $\begin{array}{l}\text { Anykščiai, } B B R_{4} \\
(2017 / 04 / 28)\end{array}$ & $\begin{array}{r}\text { Šašaičiai, } B B R_{4} \\
(2017 / 04 / 27)\end{array}$ & 25 & 0.98 & $<0.0001$ \\
\hline \multicolumn{5}{|l|}{ Bud set (date) } \\
\hline $\begin{array}{l}\text { Anykščiai, } B S \operatorname{Set}_{4} \\
(2017 / 09 / 15)\end{array}$ & Ludza, $B S e t_{4}(2016 / 09 / 15)$ & 11 & 0.82 & Ns \\
\hline $\begin{array}{l}\text { Šašaičiai, } \text { BSet }_{4} \\
(2017 / 09 / 16)\end{array}$ & Ludza, BSet $_{4}(2016 / 09 / 15)$ & 11 & 0.87 & $<0.05$ \\
\hline $\begin{array}{l}\text { Anykščiai, } \text { BSet }_{4} \\
(2017 / 09 / 15)\end{array}$ & $\begin{array}{r}\text { Šašaičiai, } \text { BSet }_{4} \\
(2017 / 09 / 16)\end{array}$ & 25 & 0.92 & $<0.0001$ \\
\hline
\end{tabular}

burst and late bud set compared to the trial means (Fig. 4). These observations are in accordance with Olson et al. [38] who showed that trees adapted to southern latitudes needed a greater temperature sum accumulation before bud flush than trees adapted to northern latitudes. The hybrids between $P$. maximowiczii $\times P$. trichocarpa $(\mathrm{M} \times \mathrm{T})$ showed better adaptation to the climate in our southernmost trials in the Baltic Sea Region. The $\mathrm{M} \times \mathrm{T}$ hybrids were characterized by earlier bud burst and a few days later bud set compared to the trial mean, which resulted in sufficient growth of these hybrids in southernmost trials (Anykščiai, Šašaičiai, Arlösa) in the current study. Our results are in concordance with a study from a geographically close location in northern Poland (N 54 $4^{\prime}$ $26^{\prime \prime}$, E $20^{\circ} 30^{\prime} 4^{\prime \prime}$ ), where "OP42" planted at similar spatial density as in our study, had significantly higher 6th-year biomass than $\mathrm{N} \times \mathrm{D}$ hybrids from southern and central Europe [39].

However, different strategies for growth rhythm may result in sufficient growth. For example, at Ludza, the clones with intermediate bud set (i.e., the clonal values not significantly different from the trial mean), such as the provenance hybrids within P. trichocarpa ( $\left.\mathrm{T} \times \mathrm{T}_{\mathrm{SLU}}\right)$, "26.1" and " 23.4 ", were among the top-performing clones as well as those with relatively late bud set ( e.g., $\mathrm{T} \times \mathrm{D}$ hybrids; S5). However, the short testing period (4 years) without early autumn frosts might have been favorable for the hybrids with late bud set $(\mathrm{M} \times \mathrm{T}$, $\mathrm{T} \times \mathrm{T}_{\mathrm{REF}}, \mathrm{T} \times \mathrm{D}$, and $P$. tremula $\times P$. tremuloides; $\left.\mathrm{S} 5\right)$. In addition, we might have missed out some portion of variability in bud set as the majority of clones had reached final stages of growth cessation at the time of inventory. This, however, would not significantly affect the main conclusions from this work. Despite relatively late inventories of bud set in the Baltic trials, the genotypic variation in bud set between clones was considerably higher than the genotypic variation in bud burst and growth. Furthermore, the relatively high residual variance component $\sigma_{\mathrm{e}}{ }^{2}=59.4 \%$ for bud set reflects the large effect of environmental cues, e.g., autumn temperatures, on this phenology trait in Ludza (Table 5). Therefore, clones with 
Fig. 4 Average clonal values of a volume index, $v_{i}$, $\mathbf{b}$ score for bud burst, $B B R$, and $\mathbf{c}$ score for bud set, BSet of different hybrid/ species groups of poplar clones in six trials in Baltic Sea Region along a latitude gradient. Abbreviations of the various hybrid/species groups are described in Table 2. Following clones are included in this figure:

$\mathrm{T} \times \mathrm{T}_{\text {SLU1 }}(26.1 ; 44.11 ; 23.4)$; $\mathrm{T} \times \mathrm{T}_{\text {SLU2 } 2}(21.9 ; 15.7) ; \mathrm{M} \times \mathrm{T}$ (OP42; OP41); T×D (70045/1; 69.037/2); N×M (Max1, Max3, Max4); N×D (AF13, AF34; AF6; AF7; AF3); T (PG2-25; PG2-28; PG2-22); B (FN5-4; FN3-20). SE of clonal values for each clone is presented in S2-S7
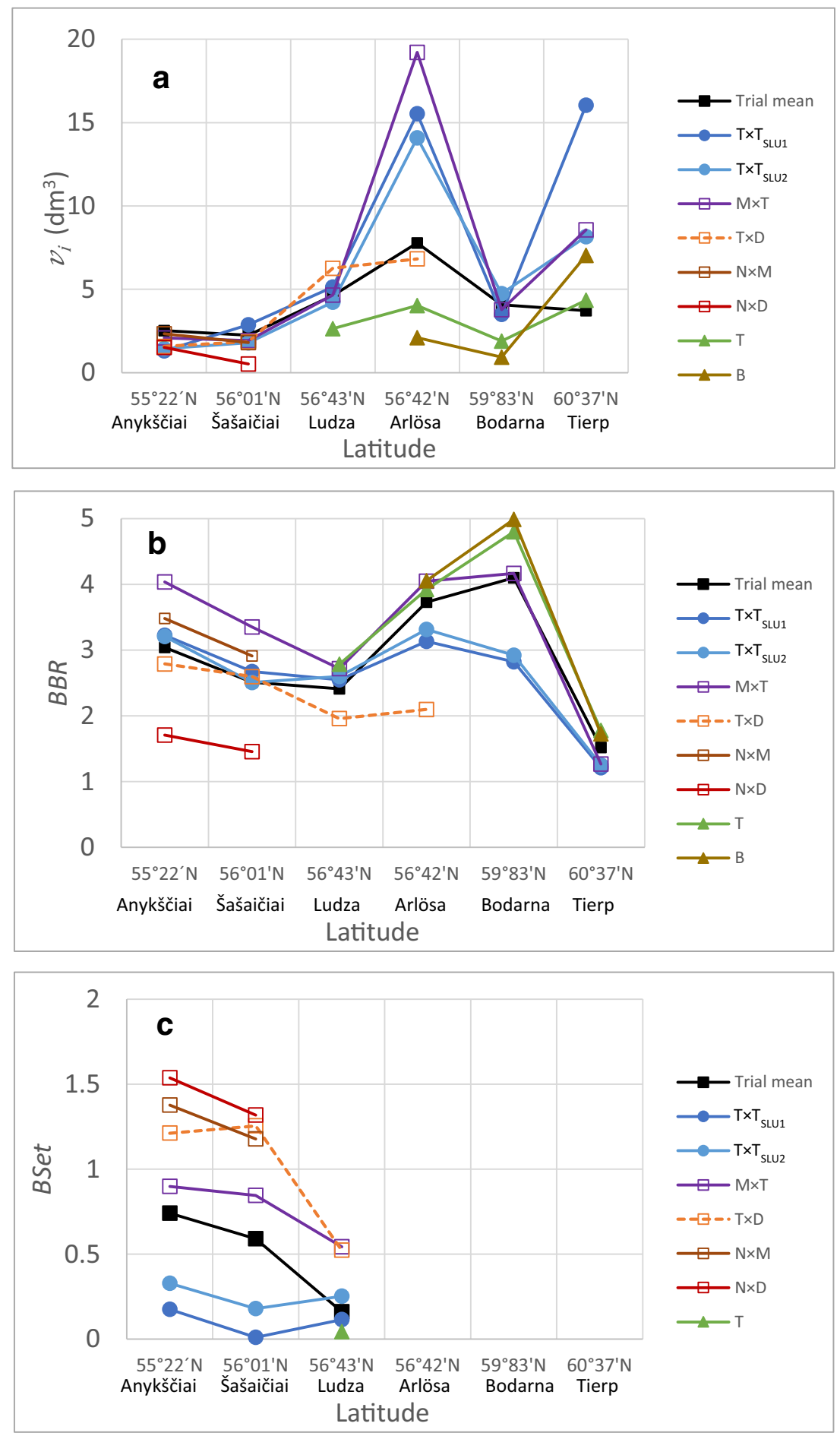

too late bud set in relation to the trial mean do not have improved growth compared to the clones with intermediate bud set and should not be planted in commercial plantations.

Provenance hybrids of $P$. trichocarpa $\left(\mathrm{T} \times \mathrm{T}_{\mathrm{SLU}}\right)$, such as clones "23.4" and "26.1," which were characterized by intermediate bud burst and intermediate bud set compared to the trial means and reference clones (S2-S7), had superior growth in the northernmost trials at Tierp and Bodarna, central
Sweden and at Ludza in eastern Latvia. These provenance hybrids show optimal adaptation to a relatively short growing season at latitudes around $60^{\circ} \mathrm{N}$ by an optimal use of growing season that is 177-210 days long with a sum of growing degree days between 1471 and 1787 at the base temperature of $5^{\circ} \mathrm{C}$.

The adaptability of clones to grow in different environments is not necessarily defined only by their phenology 

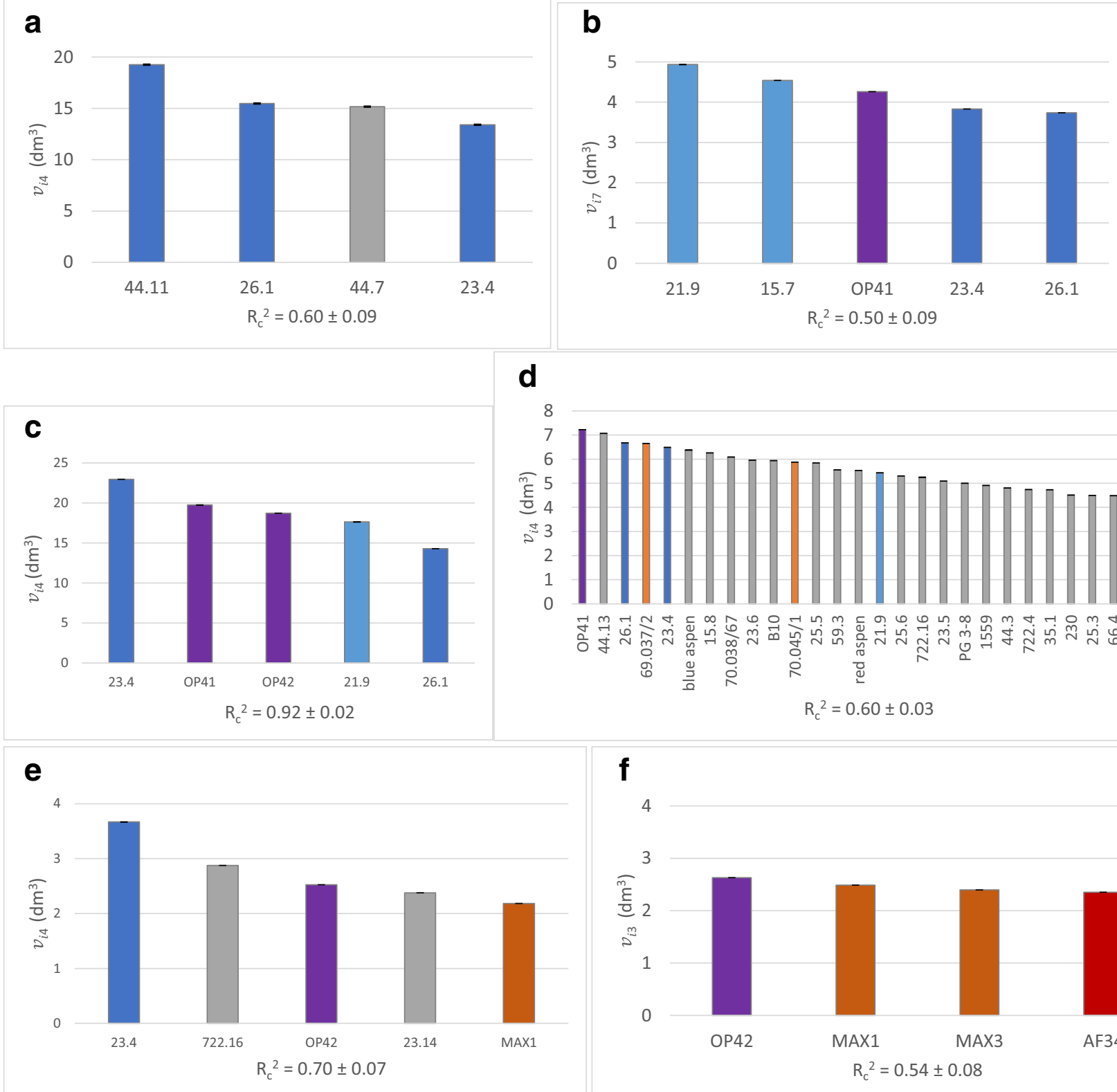

Fig. 5 Ranking of clones according to their clonal values for volume index $\left(v_{i}\right)$ in Swedish and Baltic clonal trials. Clones with significantly higher volume indices compared to the respective mean values for specific trials are presented. Figures are grouped according to latitudes in this study: northernmost (a - Tierp, b - Bodarna), middle (c - Arlösa,

[40] but also by their physiological and morphological parameters [41], which were not examined here. For example, the $\mathrm{T} \times \mathrm{D}$ hybrid "69.037/2," a clone with relatively late bud burst and bud set, allocated relatively more biomass to roots than wild $P$. trichocarpa clones from continental parts of Canada in Prince George in an outdoors pot experiment in Central Sweden, where plant responses to water and nutrient stress were studied [42]. The authors predicted the suitability of this particular clone for sandy soils, as was the case at our Ludza trial in eastern Latvia and at Arlösa in southern Sweden (Table 1; S1).

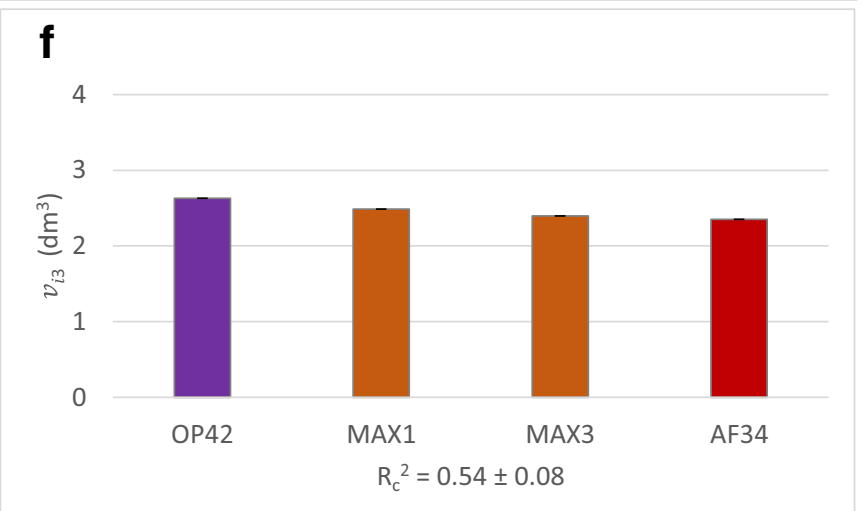

d - Ludza), and southernmost (e - Sasaiciai, $\mathbf{f}$ - Anyksciai) trials. $R_{\mathrm{G}}{ }^{2}$ is the repeatability of the clonal means. The different color, identifying clones from specific hybrid/species groups, follow the color pattern in Fig. 4. The clones not involved in Fig. 4 are presented in gray

The heritability estimates and coefficient of genotypic variation are used in breeding for comparison of genetic variation in traits and to evaluate the possibility for selection in different environments [43]. The heritability estimates for bud burst and bud set in the current study were higher than those for growth traits, which is in accordance with earlier studies on growth and adaptation of poplar hybrids [18, 26, 36, 37, 44]. The importance of spring phenology for the fitness of the trees in the Lithuanian climate is reported also by Pliura et al. [18] 
with higher broad-sense heritabilities for spring phenology than for autumn leaf senescence.

\section{Genotype-by-environment interactions}

Evaluation of clonal trials with poplars and selection of clones that are adapted to local climates is a prerequisite for commercial deployment [41, 45-48], which aims to support local markets with woody biomass [49]. Genotype-byenvironment interactions in biomass growth and phenology of poplar clones [16, 17, 48, 50-52] are important information for optimal development of adapted clonal material to specific growth environments. Our trials had variable climatic and edaphic conditions, indicating, as in earlier studies, that in addition to proper adaptation to local climate, rainfall during the actual growing season and soil type have significant impact on growth of poplars [53, 54].

Pairwise comparison of the six trials in different climates in the Baltic Sea region identified significant $\mathrm{G} \times \mathrm{E}$ interactions. These interactions were illustrated here as change in rankings of poplar clones that were common to pairs of trials (Table 7) and to all six trials (Fig. 6). Two main breeding strategies are used to deal with $\mathrm{G} \times \mathrm{E}$ interactions in breeding programs: (1) selection of clones with stable growth and broad adaptation across the environments and (2) selection of clones that are well adapted to each climatic region $[55,56]$. Cost-efficient cultivation of woody crops requires maximized growth and survival of planted material per area in combination with high value of the harvested biomass for local industries. Consequently, matching clones with specific climatic regions would maximize yield of this woody crop in northern Europe with variable climatic zones along the latitude cline. Evaluation of clonal trials, as here, gives a hint about clones that should proceed to final evaluation in yield trials. Based on the growth response of individual clones, we could identify three distinct breeding zones.

The largest breeding zone consists of the areas in southern Sweden, central Sweden (up to the Bodarna trial), Latvia and western Lithuania, where intermediate bud burst combined with intermediate bud set results in better growth (breeding zone 1). The southernmost region in this study-eastern Lithuania (Anykščiai) - represents a separate breeding zone for poplars (breeding zone 2). In this region, which is the northern margin of the natural distribution of $P$. nigra, clones with relatively early bud burst and intermediate bud set were superior in terms of volume growth. The separation of eastern Lithuania as a different breeding zone is a contrasting result to our previous study, which showed consistent ranking of poplar clones in the Baltic Sea Region by using data on leaf phenology and ambient air temperature [57]. All the trials analyzed in the last-mentioned study, belong to the breeding zone 1 identified in the current study, except the trial at Anykščiai. The difference between the two studies is that current study (1) uses also growth in addition to phenology as a criterion to rank poplar clones and (2) the number of analyzed clones is higher in the pairs of trials in current study, compared to the number of analyzed clones in all six trials analyzed by Vico et al. [57]. In addition, (3) the type B genotypic correlations, as a method to compare clonal rankings in current study, take into account also different heritabilities of traits and different harmonic means of replications per clone in pairs of trials. As rankings of clones in Anykščiai and Ludza regarding both phenology and growth were not correlated (Table 7), we suggest Anykščiai region (eastern Lithuania) as a separate breeding zone. Finally, the northernmost region of central Sweden, Tierp, outlines as a third breeding zone, where combination of intermediate bud burst and early bud set in relation to the trial means resulted in better growth (breeding zone 3).
Fig. 6 Volume index $\left(v_{i}\right)$ of five common clones in all six trials in the Baltic Sea Region along a latitude gradient

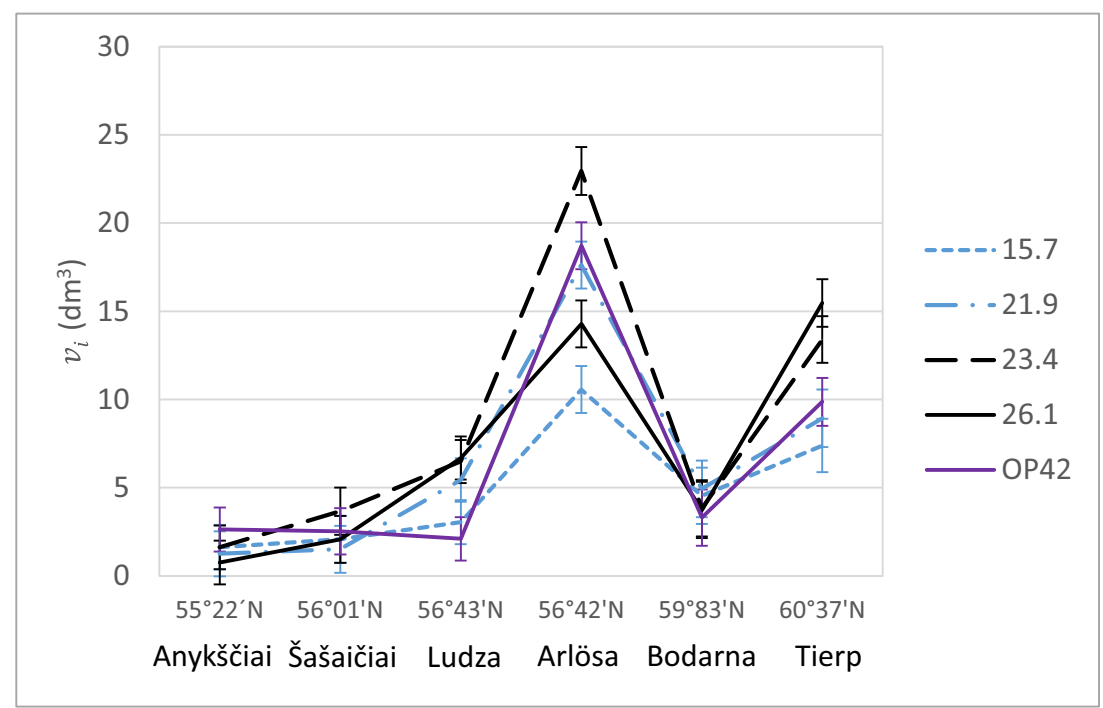




\section{Breeding goals for the North European market}

In Sweden, the production systems with fast-growing trees are designed to deliver wood in dimensions that are suitable for the existing pulping industry. Populus hybrids reach high growth rate in terms of mean annual increment $(\mathrm{MAI}=15$ $\mathrm{m}^{3} \mathrm{ha}^{-1}$ ) at a plantation age of 9 to 10 years in southern Sweden at $55^{\circ} \mathrm{N}[58]$ and $6 \mathrm{~m}^{3} \mathrm{ha}^{-1}$ in Northern Sweden at latitude $63^{\circ} \mathrm{N}$ [59]. MAI continues to increase after this age, and culminates with MAI $=20-30 \mathrm{~m}^{3} \mathrm{ha}^{-1}$ year $^{-1}$ after 20 years in Southern Sweden [3-5, 60]. During the rotation time of 20 years, the dimensions of poplars reach suitable sizes to produce assortments for diverse markets: pulpwood for pulp industry or biorefineries at first hand and secondly, tops and branches for bioenergy. In the Baltic States, the industry that manufactures wood fibreboards prevails. Poplar wood has also potential as a feedstock for production of liquid biofuels [61]. Recent advances in bioenergy research in Scandinavia are also investigating possibilities to use woody biomass for production of ethanol [62]. Innovative processes for a pulp industry are developing, which aim at more efficient biomass fractionation for future biorefineries to produce lignin oils and textile fiber from fast-growing deciduous trees [63, 64]. Fastgrowing poplars would be attractive as raw material for all of these industries. A modeling study suggests that an increased area planted with fast-growing Populus species in medium rotations would improve both volume production and profitability to the same or higher level as the cultivation of longrotation Norway spruce (Picea abies (L.) Karst.) in Sweden [65]. Regardless of the end-use of poplar as raw material, a future breeding program for this fast-growing woody crop needs to focus on high production capacity of stemwood. Our study confirms earlier findings that bud burst and bud set are likely controlled by different genes, as these adaptive traits within our trials were not correlated [36]. This finding paves a reliable ground for breeding poplars for regions with different photoperiods. Our investigation contributes to the emergence of a specific breeding program for the Baltic Sea Region by identifying large genotypic variation in growth and phenology traits in available material in local climates. Several new clones, identified in the current study, are suitable for commercial deployment in colder climates in central Sweden and in the Baltic States. Furthermore, the current study found some evidence that in addition to the major commercial hybrid poplar clone "OP42" in southern Sweden [66], there are several alternative clones suitable for establishment of large-scale plantations in different climates in Sweden and in the Baltic countries.

Future studies should follow up if the preliminary division into three different breeding zones-(1) southern and central Sweden, Latvia, western Lithuania, (2) eastern Lithuania, and (3) coastal areas of central Sweden (Tierp) - is correct at later stages of this woody crop. As clonal site suitability may also vary with rotation length [67], this evaluation after 4 years' growth needs to be complemented with growth assessments at later stages of these trials. Several earlier studies have shown, however, that top clones according to initial growth were also the top clones at greater age, although the ranking of initial top clones changed $[45,50,68]$. On an area basis, the changes in relative clonal rankings in stem volume growth and survival play a significant role in total wood production per planted area. Hence, this evaluation of single-tree plots needs to be complemented by evaluation of yield trials with monoclonal plots, as estimates of volume yields from such plots reflect better the biomass production potential on an area basis and the magnitude of difference in volume production between different clones [69].

To conclude, commercial deployment of poplars requires clones that effectively use the short growing season at northern latitudes. Relocation of clones with southern origin to northern latitudes does not result in effective use of the growing season in the north owing to the mismatch of both spring and autumn phenology of these clones at northern latitudes. Relatively late bud burst and bud set of genotypes of southern origin do not result in better volume growth in the north compared to poplar hybrids with intermediate/early bud burst and bud set matched for northern climate by breeding.

Supplementary Information The online version contains supplementary material available at https://doi.org/10.1007/s12155-021-10262-8.

Acknowledgements We are grateful to three anonymous reviewers and the editor of this special issue, who provided valuable suggestions, which improved the previous version of the manuscript. The analyses of the results were supported by SweTree Technologies. Discussions with Lars-George Hedlund, Mindaugas Šilininkas, Henrik Söderberg, Uno Brinnen, Bo Jansson, Magnus Hertzberg, and Marijke Steenackers and the statistician at the Department of Crop Production Ecology, Johannes Forkman, are warmly acknowledged. Prof. Martin Weih commented on the manuscript and emeritus researcher David Clapham commented and revised the English language of this manuscript.

Author contribution Anneli Adler: establishment and inventory of the clonal trials, development of the concept, analyses of data, writing the original draft, reviewing and editing, funding acquisition. Almir Karacic: establishment and inventory of the clonal trials, development of the concept, co-writing the introduction, reviewing and editing, funding acquisition. Ann-Christin Rönnberg Wästljung: support to statistical analyses and result generation, development of the concept, reviewing and editing, funding acquisition. Ulf Johansson: establishment and inventory of the clonal trials, development of the concept, reviewing and editing. Kaspars Liepins: establishment and inventory of the clonal trials, development of the concept, reviewing and editing. Audrius Gradeckas: establishment and inventory of the clonal trials, development of the concept. Lars Christersson: initiator of poplar testing on Northern latitudes, development of the concept, reviewing and editing the manuscript. 
Funding Open access funding provided by Swedish University of Agricultural Sciences. Swedish Research Council FORMAS, grant number 942-2016-20001 "Climate-adapted poplar through more efficient breeding and better tools for matching genotype and site - developing the poplar bio-economy market in Sweden and the Baltic Region"

Swedish Energy Agency, project number 45903-1 (registration number 2018-001188) "Cotton-substitute and biofuels from fastgrowing trees by catalytic fractionation."

SweTree Technologies AB has initiated and financed the establishment and inventories of the Swedish trials.

Södra Latvija (former Bergvik SIA) established and financed the inventories in the Ludza trial in Eastern Latvia.

Euromediena UAB in cooperation with Lithuanian Forest Research Institute and SweTree Technologies established and inventoried the clonal trials in Eastern and Western Lithuania within EUREKA Eurostars project 8443 ! during the period of 2014-2016.

Writing the manuscript was supported financially by a grant to Prof. Martin Weih by The Swedish Research Council Formas (project number 942-2016-1) and by a grant to Prof. Joseph Samec by Swedish Energy Agency (project number 45903-1, registration number 2018-001188).

Data availability The data analyzed in this manuscript are available from the corresponding author upon request.

\section{Declarations}

Conflict of interests The authors declare no competing interests.

\section{References}

1. FAO, Improving lives with poplars and willows. Synthesis of Country Progress Reports. 24th Session of the International Poplar Commission, Dehradun, India, 30 Oct-2 Nov 2012., Working Paper IPC/12, Forest assessment, management and conservation division, FAO, Rome, 2012, p. 98 pp.

2. J.G. Isebrands, J. Richardson, Poplars and willows: trees for society and the environment, 2014.

3. Rytter L, Ingerslev M, Kilpelainen A, Torssonen P, Lazdina D, Lof M, Madsen P, Muiste P, Stener L-G (2016) Increased forest biomass production in the Nordic and Baltic countries - a review on current and future opportunities. Silva Fennica 50(5)

4. Christersson L (2010) Wood production potential in poplar plantations in Sweden. Biomass \& Bioenergy 34(9):1289-1299

5. Rytter L, Johansson T, Karacic A, Weih M (2011) Investigation for a Swedish Research Program on the Genus Populus (Orienterande studie om ett svenskt forskningsprogram för poppel) In Swedish. Skogforsk - The Forestry Research Institute of Sweden, Uppsala, p 212

6. Ilstedt B (1996) Genetics and performance of Belgian poplar clones tested in Sweden. Forest Genetics 3(4):183-195

7. Christersson L (2008) Poplar plantations for paper and energy in the South of Sweden. Biomass \& Bioenergy 32(11):997-1000

8. B. Karlsson, M. Werner, L.G. Stener, Resultat från två klonförsök med poppel, Arbetsrapport från SkogForsk nr 319, Uppsala, 1996, p. $16 \mathrm{pp}$.

9. L.G. Stener, Resultat från sydsvenska klontester med poppel, Skogforsk2004.

10. L.G. Stener, Tillväxt, vitalitet och densitet för kloner av hybridasp och poppel i sydsvenska fältförsök, Arbetsrapport från SkogForsk nr 717, Uppsala, 2010, p. 50 pp.

11. Farmer RE (1993) Latitudinal Variation In Height and Phenology of Balsam Poplar. Silvae Genetica 42(2-3):148-153
12. R. Lutter, A. Tullus, T. Tullus, H. Tullus, Spring and autumn phenology of hybrid aspen (Populus tremula L. x P. tremuloides Michx.) genotypes of different geographic origin in hemiboreal Estonia, New Zealand Journal of Forestry Science 46 (2016).

13. S.G. Schreiber, C. Ding, A. Hamann, U.G. Hacke, B.R. Thomas, J.S. Brouard, Frost hardiness vs. growth performance in trembling aspen: an experimental test of assisted migration, Journal of Applied Ecology 50(4) (2013) 939-949.

14. R.Y. Soolanayakanahally, R.D. Guy, N.R. Street, K.M. Robinson, S.N. Silim, B.R. Albrectsen, S. Jansson, Comparative physiology of allopatric Populus species: geographic clines in photosynthesis, height growth, and carbon isotope discrimination in common gardens, Frontiers in Plant Science 6 (2015).

15. Savage JA, Cavender-Bares J (2013) Phenological cues drive an apparent trade-off between freezing tolerance and growth in the family Salicaceae. Ecology 94(8):1708-1717

16. Evans LM, Kaluthota S, Pearce DW, Allan GJ, Floate K, Rood SB, Whitham TG (2016) Bud phenology and growth are subject to divergent selection across a latitudinal gradient in Populus angustifolia and impact adaptation across the distributional range and associated arthropods. Ecology and Evolution 6(13):45654581

17. Stener LG, Westin J (2017) Early growth and phenology of hybrid aspen and poplar in clonal field tests in Scandinavia. Silva Fennica 51(3)

18. Pliura A, Suchockas V, Sarsekova D, Gudynaite V (2014) Genotypic variation and heritability of growth and adaptive traits, and adaptation of young poplar hybrids at northern margins of natural distribution of Populus nigra in Europe. Biomass \& Bioenergy 70:513-529

19. Howe GT, Saruul P, Davis J, Chen THH (2000) Quantitative genetics of bud phenology, frost damage, and winter survival in an F2 family of hybrid poplars. Theoretical and Applied Genetics 101(4):632-642

20. B. Ilstedt, Breeding strategy for poplar Populus trichocarpa in Sweden, Norwegian Journal of Agricultural Sciences (18, Supplement) (1994) 39-45.

21. Ilstedt B (2005) Anpassning av Populus trichocarpa, jättepoppel, till svenskt klimat. In: Christersson L, Verwijst T (eds) Proceedings from a Poplar seminar at the Department of Short Rotation Forestry. Swedish University of Agricultural Sciences, Uppsala, pp 47-50

22. G. Redalen, Hageselskapets sortliste. In Norwegian. [In English: the list of varieties from gardeners society]. 10th Edition., Det Norske Hageselskap., Oslo, 2006.

23. SMHI, Open data. Swedish Meteorological and Hydrological Institute, 2020.

24. L.V.G.u.M. Centrs, Data service at Latvian Environment, Geology and Meteorology Centre, 2020.

25. L.H. Tarnyba, Data service at Lithuanian Hydrometeorological Service, 2018.

26. McKown AD, Guy RD, Klapste J, Geraldes A, Friedmann M, Cronk QCB, El-Kassaby YA, Mansfield SD, Douglas CJ (2014) Geographical and environmental gradients shape phenotypic trait variation and genetic structure in Populus trichocarpa. New Phytologist 201(4):1263-1276

27. Pellis A, Laureysens I, Ceulemans R (2004) Genetic variation of the bud and leaf phenology of seventeen poplar clones in a short rotation coppice culture. Plant Biology 6(1):38-46

28. W.A. Becker, Manual of quantitative genetics, 1984.

29. Burdon RD (1977) Genetic correlation as a concept for studying genotype-environment interaction in forest tree breeding. Silvae Genetica 26(5-6):168-175

30. White TL, Adams WT, Neale DB (2007) Quantitative genetics polygenic traits, heritabilities and genetic correlations. In: White 
TL, Adams WT, Neale DB (eds) Forest genetics. CABI, Wallingford, UK, pp 113-148

31. Pliura A, Zhang SY, MacKay J, Bousquet J (2007) Genotypic variation in wood density and growth traits of poplar hybrids at four clonal trials. Forest Ecology and Management 238(1-3):92-106

32. Michelson IH, Ingvarsson PK, Robinson KM, Edlund E, Eriksson ME, Nilsson O, Jansson S (2018) Autumn senescence in aspen is not triggered by day length. Physiologia Plantarum 162(1):123-134

33. M. Diekmann, Deciduous forest vegetation in boreo-nemoral Scandinavia. Acta Phytogeographica Suecica 80, Uppsala University, Opulus Press, Uppsala, 1994, p. 120.

34. Brumelis G, Artistova A, Elferts D, Kasparinskis R, Nikodemus O, Amatniece V, Rendenieks Z (2019) Effects of stand-level and landscape factors on understorey plant community traits in broad-leaved forest of the boreo-nemoral zone in Latvia. Forest Ecology and Management 434:264-278

35. Rimkus E, Edvardsson J, Kazys J, Pukiene R, Lukosiunaite S, Linkeviciene R, Corona C, Stoffel M (2019) Scots pine radial growth response to climate and future projections at peat and mineral soils in the boreo-nemoral zone. Theoretical and Applied Climatology 136(1-2):639-650

36. T.J. Richards, A. Karacic, R.-P. Apuli, M. Weih, P.K. Ingvarsson, A.C. Ronnberg-Wastljung, Quantitative genetic architecture of adaptive phenology traits in the deciduous tree, Populus trichocarpa(Torr. and Gray), Heredity (2020).

37. Karacic A, Adler A, Weih M, Christersson L (2021) ana analysis of poplar growth and quality traits to facilitate identification of climate-adapted plant material for Sweden. In press. Bioenergy Research

38. M.S. Olson, N. Levsen, R.Y. Soolanayakanahally, R.D. Guy, W.R. Schroeder, S.R. Keller, P. Tiffin, The adaptive potential of Populus balsamifera L. to phenology requirements in a warmer global climate, Molecular Ecology 22(5) (2013) 1214-1230.

39. Niemczyk M, Kaliszewski A, Jewiarz M, Wrobel M, Mudryk K (2018) Productivity and biomass characteristics of selected poplar (Populus spp.) cultivars under the climatic conditions of northern Poland. Biomass \& Bioenergy 111:46-51

40. McKown AD, Klapste J, Guy RD, El-Kassaby YA, Mansfield SD (2018) Ecological genomics of variation in bud-break phenology and mechanisms of response to climate warming in Populus trichocarpa. New Phytologist 220(1):300-316

41. Niemczyk M, Hu Y, Thomas BR (2019) Selection of poplar genotypes for adapting to climate change. Forests 10(11)

42. Karacic A, Weih M (2006) Variation in growth and resource utilisation among eight poplar clones grown under different irrigation and fertilisation regimes in Sweden. Biomass \& Bioenergy 30(2):115-124

43. Houle D (1992) Comparing evolvability and variability of quantitative traits. Genetics 130(1):195-204

44. Guerra FP, Richards JH, Fiehn O, Famula R, Stanton BJ, Shuren R, Sykes R, Davis MF, Neale DB (2016) Analysis of the genetic variation in growth, ecophysiology, and chemical and metabolomic composition of wood of Populus trichocarpa provenances. Tree Genetics \& Genomes 12(1)

45. Kaczmarek DJ, Coyle DR, Coleman MD (2013) Survival and growth of a range of Populus clones in central South Carolina USA through age ten: do early assessments reflect longer-term survival and growth trends? Biomass \& Bioenergy 49:260-272

46. Schreiber SG, Hamann A, Hacke UG, Thomas BR (2013) Sixteen years of winter stress: an assessment of cold hardiness, growth performance and survival of hybrid poplar clones at a boreal planting site. Plant Cell and Environment 36(2):419-428

47. Stettler RF, Fenn RC, Heilman PE, Stanton BJ (1988) Populustrichocarpa $\mathrm{x}$ Populus-deltoides hybrids for short rotation culture variation patterns and 4-year field performance. Canadian Journal of Forest Research-Revue Canadienne De Recherche Forestiere 18(6):745-753

48. Zalesny RS Jr, Hall RB, Zalesny JA, McMahon BG, Berguson WE, Stanosz GR (2009) Biomass and genotype x environment interactions of populus energy crops in the Midwestern United States. Bioenergy Research 2(3):106-122

49. Q. Ma, A. Lebedys, Markets, Trends and Outlook, in: J.G. Isebrands, J. Richardson (Eds.) Poplars and Willows: trees for society and the environment, 2014, pp. 562-576.

50. Miller RO (2018) Growth variation among hybrid poplar varieties in Michigan. USA and the implications for commercial biomass production, bioenergy research 11(4):816-825

51. Nelson ND, Berguson WE, McMahon BG, Cai MJ, Buchman DJ (2018) Growth performance and stability of hybrid poplar clones in simultaneous tests on six sites. Biomass \& Bioenergy 118:115-125

52. Cooper HF, Grady KC, Cowan JA, Best RJ, Allan GJ, Whitham TG (2019) Genotypic variation in phenological plasticity: Reciprocal common gardens reveal adaptive responses to warmer springs but not to fall frost. Global Change Biology 25(1):187-200

53. Ghezehei SB, Nichols EG, Maier CA, Hazel DW (2019) Adaptability of populus to physiography and growing conditions in the Southeastern USA. Forests 10(2)

54. P.E. Heilman, R.F. Stettler, Genetic-variation and productivity of populus-trichocarpa and its hybrids .2. Biomass production in a 4year plantation, Canadian Journal of Forest Research-Revue Canadienne De Recherche Forestiere 15(2) (1985) 384-388.

55. Li Y, Suontama M, Burdon RD, Dungey HS (2017) Genotype by environment interactions in forest tree breeding: review of methodology and perspectives on research and application. Tree Genetics \& Genomes 13(3)

56. M.S. Kang, Quantitative genetics, genomics and plant breeding, 2002.

57. Vico G, Karacic A, Adler A, Richards T, Weih M (2021) Consistent poplar clone ranking based on leaf phenology and temperature along a latitudinal and climatic gradient in Northern Europe. Bioenergy Research In press

58. Karacic A, Verwijst T, Weih M (2003) Above-ground woody biomass production of short-rotation populus plantations on agricultural land in Sweden. Scandinavian Journal of Forest Research 18(5): 427-437

59. Rytter L, Lutter R (2020) Early growth of different tree species on agricultural land along a latitudinal transect in Sweden. Forestry 93(3):376-388

60. Fahlvik N, Rytter L, Stener LG (2019) Production of hybrid aspen on agricultural land during one rotation in southern Sweden. Journal of Forestry Research

61. Sannigrahi P, Ragauskas AJ, Tuskan GA (2010) Poplar as a feedstock for biofuels: a review of compositional characteristics. Biofuels Bioproducts \& Biorefining-Biofpr 4(2):209-226

62. J.A. Ohlsson, H.R. Hallingback, M. Jebrane, A.E. Harman-Ware, T. Shollenberger, S.R. Decker, M. Sandgren, A.C. RonnbergWastljung, Genetic variation of biomass recalcitrance in a natural Salix viminalis (L.) population, Biotechnology for Biofuels 12 (2019).

63. Galkin MV, Samec JSM (2016) Lignin Valorization through catalytic lignocellulose fractionation: a fundamental platform for the future biorefinery. Chemsuschem 9(13):1544-1558

64. Galkin MV, Smit AT, Subbotina E, Artemenko KA, Bergquist J, Huijgen WJJ, Samec JSM (2016) Hydrogen-free catalytic fractionation of woody biomass. Chemsuschem 9(23):3280-3287

65. Subramanian N, Bergh J, Johansson U, Nilsson U, Sallnaes O (2016) Adaptation of forest management regimes in Southern Sweden to increased risks associated with climate change. Forests $7(1)$

66. FAO, Improving lives with poplars and willows. Synthesis of Country Progress Reports. 24th Session of the International 
Poplar Commission, Dehradun, India, 30 Oct-2 Nov 2012., Working Paper IPC/12., Forest Assessment, Management and Conservation Division, FAO, Rome., 2012, p. 93.

67. S.B. Ghezehei, J. Wright, R.S. Zalesny, Jr., E.G. Nichols, D.W. Hazel, Matching site-suitable poplars to rotation length for optimized productivity, Forest Ecology and Management 457 (2020).

68. Nielsen UB, Madsen P, Hansen JK, Nord-Larsen T, Nielsen AT (2014) Production potential of 36 poplar clones grown at medium length rotation in Denmark. Biomass \& Bioenergy 64:99-109

69. R. Ceulemans, G. Scarasciamugnozza, B.M. Wiard, J.H. Braatne, T.M. Hinckley, R.F. Stettler, J.G. Isebrands, P.E. Heilman,
Production physiology and morphology of populus species and their hybrids grown under short rotation.1. Clonal comparisons of 4-year growth and phenology, Canadian Journal of Forest Research-Revue Canadienne De Recherche Forestiere 22(12) (1992) 1937-1948.

Publisher's Note Springer Nature remains neutral with regard to jurisdictional claims in published maps and institutional affiliations. 